\title{
DE KRITISCHE RENTABILITEIT VAN INTERNATIONALE CONCERNS: \\ EEN KWANTITATIEVE BENADERING
}

\author{
door Dr. L. Traas*)
}

\section{Inleiding}

Het vraagstuk van het rentabiliteitscriterium dat in de onderneming dient te worden gehanteerd bij de evaluatie van nieuwe investeringen staat de laatste tijd in de bedrijfseconomie sterk in de belangstelling.

Voor een deel vindt deze belangstelling zijn oorsprong in de bij het bedrijfsleven bestaande behoefte voor de hier liggende problemen een verantwoorde oplossing te verkrijgen. Daarnaast is echter ook een belangrijke stimulans uitgegaan van verschillende nieuwe denkbeelden die in het afgelopen decennium in de theorie van de financiering naar voren zijn gebracht ${ }^{1}$ ). Deze nieuwe denkbeelden bleken een uitermate vruchtbaar uitgangspunt voor een verdere uitbouw van het juist op het onderhavige terrein voorheen nog slechts gebrekkige theoretische apparaat.

Door de inspanning van verschillende prominente economen is dit theoretische apparaat inmiddels reeds uitgegroeid tot een imposant bouwwerk, waarvan - naar het schijnt - de contouren thans wel ongeveer vastliggen doch waaraan nog bij voortduring enthousiast wordt gewerkt ter verdere verfraaiing en versteviging van de onderdelen ${ }^{2}$ ).

Hoewel dus op het terrein van de theorievorming reeds belangrijke resultaten zijn bereikt, is de verbinding met de praktijk toch nog maar nauwelijks tot stand gekomen. Het onderhavige artikel vormt een poging om in dit opzicht enige vooruitgang te boeken. Getracht zal worden op basis van de in de theorie verworven inzichten, voor een vijftal internationale concerns, het te hanteren rentabiliteitscriterium exact te kwantificeren. Blijkt deze poging succesvol dan is daarmee de operationele betekenis van het recente theoretische werk - althans in beginsel - aangetoond. In het onderzoek zijn de volgende concerns betrokken: De Koninklijke Nederlandsche Petroleum Maatschappij, Philips' Gloeilampenfabrieken, Unilever N.V., General Electric en Radio Corporation of America.

*) Dit artikel geeft weer de persoonlijke opvattingen van de schrijver en niet noodzakelijk die van de onderneming waar hij werkzaam is. Bij de analyse van de jaarverslagen der in het onderzoek betrokken concerns, alsook bij het uitvocren van de berekeningen, werd belangrijke steun verleend door Drs. D. Feenstra. Mogelijke fouten zijn uiteraard voor rekening van de schrijver.

1) Zie met name:

M. J. Gordon en E. Shapiro "Capital equipment analysis: the required rate of profit" Management Science, olstober 1956.

F. Modigliani en M. H. Miller ,The cost of capital, corporation finance and the theory of investment" American Economic Review, juni 1958.

M. H. Miller en F. Modigliani „Dividend policy, growth and the valuation of shares” Journal of Business, oktober 1961 .

M. J. Gordon ",The investment, financing and valuation of the corporation". Richard D. Irwin Inc. Homewood Ill. 1962.

2) Zie onder meer E. Solomon "The theory of financial management" Columbia University Press New York 1963;

A. A. Robichek en S. C. Meyers „Optimal Financing Decisions”. Prentice-Hall Inc. Englewood Cliffs N. J. 1965;

E. M. Lerner en W. T. Carleton ,A theory of financial analyses" Harcourt, Brace and World, Inc., New York 1966; D. Vickers "The theory of the firm: production, capital and finance". McGrawHill Inc. New York 1968; alsmede talloze tijdschriftartikelen. 
De opbouw van het artikel is als volgt. In de eerste paragraaf wordt nader uiteengezet op welk rentabiliteitscriterium het onderzoek zich precies richt en waarom juist dit rentabiliteitscriterium voor de praktijk van belang moet worden geacht. Paragraaf 2 bevat een beschrijving van het model waarvan bij de kwantificering van het rentabiliteitscriterium is uitgegaan. In paragraaf 3 worden de problemen besproken verbonden met de meting van de in de berekening op te nemen basisgrootheden. Bovendien worden in deze paragraaf ook de verkregen uitkomsten vermeld. In paragraaf 4 tenslotte, wordt nog iets gezegd over de betrouwbaarheid van de verkregen uitkomsten en over de operationele waarde daarvan.

\section{$\$ 1$ De inhoud van de begrippen kritische rentabiliteit en vermogenskosten}

Het rentabiliteitscriterium dat bij de evaluatie van nieuwe investeringen (en in beginsel ook bij de beoordeling van reeds bestaande aktiviteiten) de functie van afkapgrens vervult, wordt wel aangeduid als de kritische rentabiliteit van de onderneming ${ }^{3}$ ). Deze kritische rentabiliteit kan naar onze mening het best worden omschreven als de rentabiliteit die op het in de onderneming geïnvesteerde of nog te investeren vermogen minstens moet worden verkregen, wil de onderneming de haar gestelde doeleinden kunnen realiseren.

Uit deze omschrijving volgt dat aan het begrip kritische rentabiliteit slechts een operationele inhoud zal kunnen worden gegeven indien de doeleinden van de onderneming nader worden gespecificeerd. Over deze doeleinden bestaat bepaald geen eenheid van opvatting. Hoe ver de meningen echter ook uiteen mogen lopen, één element vindt men impliciet of expliciet toch altijd wel weer terug, n.l. het element van de ,continuïteit".

De onderneming streeft naar continuïteit, of, om het wat anders uit te drukken, naar „levensvatbaarheid”. Voor een operationele omschrijving van het begrip kritische rentabiliteit biedt dit element reeds belangrijke aanknopingspunten. Want wil de onderneming levensvatbaar blijven dan zal zij ervoor moeten zorgen dat op het door de vermogensverschaffers ter beschikking gestelde - of nog ter beschikking te stellen - vermogen minstens een zodanige beloning in uitzicht wordt gesteld, dat deze vermogensverschaffers als groep geen reden hebben hun relatie met de onderneming te verbreken of een eventueel verzoek tot uitbreiding van de relatie af te wijzen. Het probleem van de kritische rentabiliteit spitst zich hierbij toe op de vraag hoe groot deze beloning - gerekend per geïnvesteerde gulden - precies dient te zijn.

Voor de in de vorm van vreemd vermogen aangetrokken middelen kan deze vraag gemakkelijk worden beantwoord. Aan de verschaffers van vreemd vermogen zal een beloning in uitzicht moeten worden gesteld gelijk aan de prijs die op de vermogensmarkt geldt. Immers deze marktprijs (de interestvoet) zullen de vermogensverschaffers ook bij belegging elders kunnen verkrijgen en de betreffende onderneming zal met deze alternatieve mogelijkheden moeten concurreren.

Voor het eigen vermogen kan eenzelfde redenering worden gevolgd. De verschaffers van dit vermogen - bij een naamloze vennootschap de aandeelhouders zullen geen reden hebben de continuïteit te verbreken indien zij op hun belegging een beloning kunnen verwachten (in de vorm van dividend en/of koerswinst)

3) Vgl. H. Willems „De financiële structuur en de vermogenskosten in de investeringsplanning en de kostprijsberekening" Leiden 1965. 
welke overeenkomt met de beloning die op de vermogensmarkt bij belegging in andere, kwalitatief gelijkwaardige, aandelen kan worden verkregen. Daar dividend en koerswinst zullen afhangen van de netto winst die de onderneming weet te realiseren, zal uit dit marktcriterium een rentabiliteitseis voor het eigen vermogen kunnen worden afgeleid (zie hierna).

Hoewel de redenering voor het eigen vermogen volledig parallel loopt met die voor het vreemde vermogen, bestaat er toch een belangrijk verschil. Anders dan bij het vreemde vermogen zal bij het eigen vermogen het voldoen aan het marktcriterium lang niet altijd een "levenswoorwaarde" vormen voor de onderneming. Immers de ervaring leert dat de bestaande aandeelhouders zich maar zelden effectief (kunnen) verzetten tegen het in de onderneming gevoerde beleid. Wordt het criterium geweld aangedaan dan behoeft dus de continuïteit van de onderneming niet noodzakelijk in gevaar te komen.

Uit de continuïteitseis alléén zal dan ook geen eenduidig bepaalde hoogte voor de kritische rentabiliteit kunnen worden afgeleid. Daartoe zullen ook andere elementen uit de doelstelling van de onderneming in de beschouwing moeten worden betrokken. Voor wat betreft deze andere elementen zullen wij ons beperken tot de (zeer) grote ondernemingen georganiseerd in de vorm van een open naamloze vennootschap.

In de doelstelling van de zeer grote ondernemingen neemt naast - of als verlengstuk van - het streven naar levensvatbaarheid het streven naar groei een belangrijke plaats in. Met name Galbraith heeft daarop onlangs nog met nadruk gewezen ${ }^{4}$ ). Dit groeistreven wordt nodeloos geremd indien een kritische rentabiliteit wordt gehanteerd welke ligt bòven de marktprijs van het vermogen. Een hogere kritische rentabiliteit is om deze reden dan ook niet waarschijnlijk.

Een kritische rentabiliteit lager dan de marktprijs van het vermogen zal weliswaar op korte termijn de expansie bevorderen. Op lange termijn echter kan dit tot meer of minder ernstige moeilijkheden leiden.

De belangrijkste van deze moeilijkheden zijn:

- De toegang tot de emissiemarkt wordt geheel of gedeeltelijk afgesneden zodat toekomstige groeimogelijkheden wellicht niet of slechts voor een deel kunnen worden benut.

- De aandeelhouders worden ontevreden over de winstinhoudingen. Er ontstaan oppositiegroepen die een hogere uitkeringsquote eisen. Daardoor wordt de financiële standing van de onderneming aangetast.

- Het aandeel van de onderneming biedt niet meer de mogelijkheid om bestaande ondernemingen via aandelenruil over te nemen (tenzij een ernstige verwatering van het aandelenkapitaal wordt aanvaard). Overnemingen zullen dan via contante betaling moeten plaatsvinden met alle consequenties van dien voor de financiële structuur. Is deze structuur reeds zwak dan zullen mogelijk zelfs overnemingen achterwege moeten blijven en zal dus de groei worden geremd.

- Het aandeel van de onderneming wordt typisch een aandeel om een overnamebod op uit te brengen.

Wordt in de onderneming een kritische rentabiliteit gehanteerd gelijk aan de marktprijs van het vermogen dan worden vanzelfsprekend bovenstaande moeilijkheden niet automatisch vermeden. Wel bestaat dan echter de garantie dat vanuit

4) J. R. Galbraith „The New Industrial State” Hamisch Hamilton Lrd. London 1967. 
het beoordelingscriterium zèlf, géén impulsen in deze richting uitgaan. Voor de grote open naamloze vennootshap lijkt dan ook de marktprijs van het vermogen het aangewezen rentabiliteitscriterium.

De marktprijs in de bovenbedoelde zin geeft weer het offer dat, op lange termijn gezien, ten behoeve van de financiering, door de onderneming als zelfstandig instituut, dient te worden gebracht. Deze marktprijs moet daarom worden beschouwd als de kosten van het vermogen. Bij financiering met een combinatie van eigen en vreemd vermogen kunnen deze kosten (van het totale vermogen) nader worden gedefinieerd als het gewogen gemiddelde van de kosten van het eigen vermogen en de kosten (interestvoet) van het vreemde vermogen, waarbij als gewichten gelden het relatieve aandeel van het eigen resp. het vreemde vermogen.

Gebruik makend van deze terminologie kan het vorenstaande worden samengevat in de conclusie: bij de grote open naamloze vennootschap dient de kritische rentabiliteit gelijk te worden gesteld aan de kosten van het (totale) vermogen ${ }^{5}$ ).

In de volgende paragraaf zal worden onderzocht hoe deze kosten kunnen worden gekwantificeerd.

\section{$\$ 2$ Het model voor de bepaling van de vermogenskosten}

A. De kosten van bet eigen vermogen

Het is niet mogelijk de kosten van het eigen vermogen rechtstreeks uit een marktnotering af te lezen; deze zullen daaruit langs indirekte weg moeten worden afgeleid. Zoals bekend geldt ditzelfde ook voor de feitelijke interestvoet die bij belegging in reeds bestaande obligaties wordt verkregen. De berekening van de kosten van het eigen vermogen kan dan ook worden verduidelijkt door een parallel te trekken met obligaties.

De beurswaarde van een obligatie geeft weer de prijs waarvoor men de obligatie kan kopen resp. verkopen. Teneinde te kunnen vaststellen welke interestvoet daarin impliciet is begrepen gaat men uit van de regel dat bij een rationele waardering de waarde van een obligatie gelijk is aan de contante waarde van de toekomstige kasontvangsten (inclusief aflossing) die de obligatie oplevert; de contante waarde berekend met behulp van de interestvoet als disconteringsvoet. De toekomstige kasontvangsten van de obligatie zijn bekend, deze liggen immers contractueel vast, en uit de beursnotering blijkt de waarde van de obligatie. Men kan derhalve een vergelijking opstellen met één onbekende, n.l. de gezochte interestvoet, en deze daaruit oplossen. Heeft men een eeuwigdurende obligatie dan is de berekening uiterst eenvoudig. De basisvergelijking kan in dit geval worden gereduceerd tot:

$$
\text { interestvoet }=\frac{\text { jaarlijkse couponopbrengst }}{\text { beurswaarde obligatie }}
$$

Eenzelfde redenering kan men ook volgen ter berekening van de opbrengstvoet die op de vermogensmarkt bij belegging in aandelen wordt verkregen. Gesteld kan worden - en in de financieringsliteratuur wordt dit uitgangspunt vrij algemeen aanvaard - dat bij een rationele waardering van aandelen de waarde daarvan gelijk zal zijn aan de contante waarde van de kasontvangsten die aan de bezitter van het

5) Een uitvoeriger motivering alsmede een vermelding van het kader waarbinnen deze uitspraak juist kan worden geacht is gegeven in L. Traas "Het investerings- en financieringsplan van de onderneming", Samsom; Alphen a/d Rijn 1968.

m a b blz. 179 
aandeel in de toekomst zullen toevloeien; de contante waarde dan in dit geval berekend met behulp van de door de beleggers verlangde opbrengstvoet als disconteringsvoet.

Vergeleken met obligaties bestaat er bij de aandelen slechts dit verschil dat de toekomstige kasontvangsten (dividenden, claimopbrengsten, enz.) niet tevoren bekend zijn. De waarden daarvoor zullen moeten worden geschat en dan nog wel de waarden zoals die door de beleggers in meerderheid worden gezien. (Van dit schattingsprobleem wordt echter voorlopig nog geabstraheerd).

Neemt men als uitgangspunt dat de onderneming een in beginsel oneindige levensduur heeft, dan geldt voor de waarde van een aandeel:

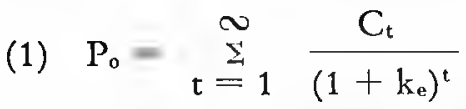

waarbij $\mathrm{P}_{0}$ is de beurswaarde van het aandeel op tijdstip nul, $\mathrm{C}_{t}$ de kasontvangsten in periode $t$ voortvloeiend uit het bezit van een aandeel en $k_{e}$ de door de aandeelhouders op hun belegging verlangde opbrengstvoet.

Stel nu dat voor een onderneming de volgende gegevens resp. verwachtingen gelden:

- De netto winst per aandeel zal in het komende jaar $Y_{1}$ bedragen.

- Jaarlijks zal van de netto winst een fractie b worden ingehouden en - derhalve een fractie (1-b) worden uitgekeerd.

- Op gezette tijden zullen in de toekomst emissies van nieuwe aandelen plaatsvinden met voorkeursrechten voor de bestaande aandeelhouders. Deze emissies zullen gemiddeld per jaar een fractie u van de netto jaarwinst bedragen.

- Additioneel in de onderneming geïnvesteerd eigen vermogen zal een rentabiliteit opleveren nà aftrek van belastingen van $100 \mathrm{r}_{0}^{1} \%$. Deze $100 \mathrm{r}^{1} \%$ wordt differenticel bepaald d.w.z. door de additionele winst die in de toekomst wordt verkregen te relateren aan het additioneel geïnvesteerde eigen vermogen.

Wordt in eerste instantie aangenomen dat de bestaande aandeelhouders allen steeds van de hun bij emissie toekomende voorkeursrechten volledig gebruik zullen maken, dan kan op grond van bovenstaande gegevens worden berekend dat de netto winst die aan elk aandeel zal toevallen in de toekomst het volgende verloop zal hebben:

1e jaar: $Y_{1} ; 2 e$ jaar: $Y_{1}+(b+u) Y_{1} r{ }_{\theta}^{1}=Y_{1}\left[1+(b+u) r_{\theta}^{1}\right]$; 3e jaar: $Y_{1}\left[1+(b+u) r_{\theta}^{1}\right]^{2}$ enz., oplopend volgens een meetkundige reeks met de reden $\left[1+(b+u) r_{\theta}^{1}\right]$.

De kasontvangsten die de bezitter van een aandeel per saldo - d.w.z. nà inschrijving op de emissies - ter beschikking zal krijgen, zullen bij deze winstontwikkeling bedragen:

1e jaar: $\{1-(b+u)\} Y_{1}, 2 e$ jaar: $\left\{1-(b+u\} Y_{1}\left[1+(b+u) r_{e}^{1}\right]\right.$, 3e jaar: $\{1-(b+u)\} Y_{1}\left[1+(b+u) r_{e}^{1}\right]^{2} ;$ enz.

Deze gegevens maken het mogelijk de kasontvangsten $C_{t}$ nader te definiëren als: $\mathrm{C}_{\mathrm{t}}=\{1-(\mathrm{b}+\mathrm{u})\} \mathrm{Y}_{1}\left[1+(\mathrm{b}+\mathrm{u}) \mathrm{r}_{\mathrm{u}}^{1}\right]^{\mathrm{t}-1}$

$\mathrm{Na}$ substitutie geldt dan voor de waarde van een aandeel $\mathrm{P}_{\mathrm{o}}$ :

(1) $\quad P_{0}=\stackrel{\sim}{\Sigma}_{t} \frac{\{1-(b+u)\} Y_{1}\left[1+(b+u) r_{\theta}^{1}\right.}{]^{t-1}}$ 
Onder de veronderstelling dat $\mathrm{k}_{\mathrm{e}}>(\mathrm{b}+\mathrm{u}) \mathrm{r}_{\mathrm{a}}^{1}$ kan na sommering van de netto kasontvangsten $(1)^{\mathrm{a}}$ worden vereenvoudigd tot $(1)^{\mathrm{b}}$.

(1) ${ }^{b} \quad P_{o}=\frac{(1-(b+u)\} Y_{1}}{k_{e}-(b+u) r_{e}^{1}}$

Bij de afleiding van (1) ${ }^{\mathrm{b}}$ werd ervan uitgegaan dat de aandeelhouders voor de waardebepaling van de aandelen de gehele oneindige reeks van jaarwinsten en de daarmee samenhangende uitkeringen in beschouwing zullen nemen. Dit lijkt wellicht wat veel gevraagd. Aan het voorstellingsvermogen van de aandeelhouders worden aanmerkelijk minder heroïsche eisen gesteld indien wordt aangenomen dat zij hun waardeoordeel zullen baseren op de verwachte kasontvangsten gedurende een toekomstig tijdvak dat nog enigszins kan worden overzien, plus de geschatte beursprijs van het aandeel aan het einde van dat tijdvak.

Neemt men deze benadering als uitgangspunt dan krijgt men - in plaats van de basisformule (1) - de volgende vergelijking:

(2) $P_{0}-\sum_{t} \stackrel{n}{=} \frac{C_{t}}{\left(1+k_{e}\right)^{2}}+\frac{P_{n}}{\left(1+k_{e}\right)^{n}}$

waarbij $n$ het aantal jaren aangeeft van de periode dat de stroom van kasontvangsten nog uitdrukkelijk in beschouwing wordt genomen.

Wordt $C_{t}$ vervangen door de daarvoor in het voorgaande reeds afgeleide waarde en realiseert men zich dat de winst per aandeel in jaar $n\left(Y_{n}\right)$ gelijk zal zijn aan $Y_{0}\left[1+(b+u) r_{\theta}^{1}\right]^{n}$ dan kan (2) worden herschreven als

$(2)^{\mathrm{n}} \quad \mathrm{P}_{\mathrm{o}}=\stackrel{\mathrm{t}}{\mathrm{N}}=1_{\frac{\mathrm{N}}{=}} \frac{\{1-(\mathrm{b}+\mathrm{u})\} \mathrm{Y}_{1}\left[1+(\mathrm{b}+\mathrm{u}) \mathrm{r}_{\theta}^{1}\right]^{\mathrm{t}-1}}{\left(1+\mathrm{k}_{\mathrm{e}}\right)^{\mathrm{t}}}+\frac{\mathrm{P}_{\mathrm{n}}}{\mathrm{Y}_{\mathrm{n}}} \times \frac{\mathrm{Y}_{\mathrm{o}}\left[1+(\mathrm{b}+\mathrm{u}) \mathrm{r}_{\theta}^{3}\right]^{\mathrm{n}}}{\left(1+\mathrm{k}_{\mathrm{e}}\right)^{\mathrm{n}}}$

Indien nu één additionele veronderstelling wordt gemaakt $\mathrm{nl}$. dat de aandeelhouders verwachten dat aan het einde van het tijdvak van $n$ jaar de ,price earnings ratio" voor het betreffende aandeel dezelfde waarde zal hebben als in het heden; dus als geldt $\frac{P_{n}}{Y_{n}}=\frac{P_{w}}{Y_{o}}$, dan kan $(2)^{a}$ eveneens worden vereenvoudigd tot de eerder reeds gevonden uitkomst:

(1) $\mathrm{P}_{\mathrm{o}}=\frac{\{1-(\mathrm{b}+\mathrm{u})\} \mathrm{Y}_{1}}{\mathrm{k}_{\mathrm{e}}-(\mathrm{b}+\mathrm{u}) \mathrm{r}_{\mathrm{\theta}}^{\prime}}$

Bij deze tweede afleiding behoeft niet zoals hiervoor de veronderstelling te worden gemaakt $k_{e}>(b+u) r_{\theta}^{1}$. Het loslaten van de eerder als voorlopig geïntroduceerde hypothese dat de bestaande aandeelhouders bij elke emissie steeds weer volledig van de hen toekomende voorkeursrechten gebruik zullen maken, brengt geen verandering in de formule (1) ${ }^{b}$. Weliswaar zal een aandeelhouder, indien hij niet zelf inschrijft op een emissie, - b.v. in jaar $t$ - een kasuitgave besparen, doch daar staat tegenover dat hij dan in de daarop volgende jaren kasontvangsten zal derven waarvan de contante waarde in jaar $t$, bij rationele waardering exact gelijk zal zijn aan de bespaarde kasuitgave. De contante waarde van de gehele stroom van netto kasontvangsten opgenomen in het rechter deel van (1) blijft dus gelijk.

6) Zie ook L. Traas: „Het investerings- en financieringsplan van de onderneming”, Alphen aan de Rijn 1968, bli. 139-149.

${ }^{7}$ ) Deze tweede afleiding van (1) bluit aan bij de gedachtengang van Crocket en Friend. Zie J. Crockett en I. Friend "Some Estimates of the cost of capital to the Electric Utility Industry, 1954 - 1957: Comment". American Economic Review, december 1967; met name blz. 1263 en 1264. 
Kunnen voor alle in $(1)^{\mathrm{b}}$ voorkomende grootheden met uitzondering van $\mathrm{k}_{\mathrm{e}} \mathrm{de}$ relevante waarden worden vastgesteld resp. geschat dan is het mogelijk $k_{\theta}$ uit (1) op te lossen. Daartoe wordt (1) ${ }^{\mathrm{b}}$ als volgt herschreven:

(3) $k_{\mathrm{e}}=[1-(b+u)] Y_{1} / P_{o}+(b+u) r_{e}^{l}$

Stelt men het verschil tussen $r_{0}^{1}$ en $Y_{1} / P_{0}$ voor door $x$; zodat geldt $x=r_{0}^{1}-$ $Y_{1} / P_{0}$, dan kan (3) worden vereenvoudigd tot: ${ }^{8}$ )

(4) $\mathrm{k}_{\mathrm{e}}=\mathrm{Y}_{1} / \mathrm{P}_{\mathrm{o}}+\mathrm{x}(\mathrm{b}+\mathrm{u})$

Uit (4) blijkt dat de door de aandeelhouders verlangde opbrengstvoet - dat zijn de kosten van het eigen vermogen - gelijk is aan het omgekeerde van de "price earnings ratio" (vergelijk de eerder genoemde eeuwigdurende obligatie) vermeerderd met een groeicomponent waarvan de hoogte wordt bepaald door de expansie in het eigen vermogen en de toekomstige rentabiliteit.

Met uitzondering van $P_{0}$ stellen alle in het rechter deel van (4) voorkomende grootheden verwachtingswaarden voor; en wel verwachtingswaarden zoals deze op de vermogensmarkt door de aandeelhouders in meerderheid worden aangehouden met betrekking tot de betreffende onderneming. In paragraaf 3 zal worden aangegeven op welke wijze deze verwachtingswaarden kunnen worden gekwantificeerd.

\section{B. De interestvoet voor het vreemde vermogen}

De bepaling van de prijs die door de verschaffers van het vreemde vermogen wordt verlangd levert geen principiële moeilijkheden op.

Deze prijs is voor de verschillende soorten van het vreemde vermogen gelijk aan de interestvoet die voor elk van deze soorten op de vermogensmarkt wordt genoteerd. Voorzover geen rechtstreekse notering van de interestvoet plaatsvindt maar op de vermogensmarkt de prijs van de betreffende schuldtitels wordt geregistreerd (zoals bij obligaties), kan de relevante interestvoet langs indirekte weg worden bepaald op de wijze zoals besproken aan het begin van onderdeel A van deze paragraaf.

Hoewel zich dus bij de bepaling van de interestvoeten geen principiële problemen voordoen stoot men bij de uitwerking van het bovenstaande in concrete situaties toch nog op verschillende praktische moeilijkheden. In paragraaf $3 \mathrm{zal}$ daarop nader worden ingegaan.

\section{De financiële structuur en de kosten van bet totale vermogen}

$\mathrm{Nu}$ is aangegeven volgens welke gedachtengang de kosten van het eigen vermogen dienen te worden berekend en langs welke weg de relevante interestvoeten voor het vreemde vermogen kunnen worden bepaald, blijft tenslotte nog één vraagstuk open n.l. dat van het samenvoegen van deze beide componenten tot de kosten van het totale vermogen.

$\mathrm{Bij}$ het oplossen van dit vraagstuk zal in de eerste plaats aandacht moeten worden geschonken aan de verhoudingen in de financiële structuur: immers de kosten van het totale vermogen werden in $\$ 2$ gedefinieerd als het gewogen gemiddelde van de kosten van eigen en vreemd vermogen waarbij als gewichten gelden het relatieve aandeel van het eigen resp. het vreemde vermogen in de financiële structuur.

8) Zie ook L. Traas t.a.p. blz. 246.

m a b blz. 182 
Aangezien het in dit artikel niet gaat om de kosten van het totale vermogen behorende bij de optimale financiële structuur, maar om de kosten verbonden met de bestaande financiële structuur ligt het voor de hand ter bepaling van het gewogen gemiddelde uit te gaan van die verhouding tussen eigen en vreemd vermogen waarmee de onderneming ook werkelijk financiert. Concreet gezegd betekent dit dat als $E$ voorstelt het eigen vermogen, $F$ het vreemde vermogen en $K$ het totale vermogen (alle volgens de balans waarbij $\mathrm{E}+\mathrm{F}=\mathrm{K}$ ), aan de kosten van het eigen vermogen een gewicht $\mathrm{E} / \mathrm{K}$ zal moeten worden toegekend en aan de kosten van het vreemde vermogen een gewicht van $\mathrm{F} / \mathrm{K}$.

Behalve aan de verhoudingen in de financiële structuur moet bij de berekening van de kosten voor het totale vermogen ook aandacht worden geschonken aan de risico-premie die in de kosten van het eigen vermogen is verdisconteerd. De kosten van het eigen vermogen zijn in het voorgaande gelijkgesteld aan de opbrengstvoet die door de verschaffers van eigen vermogen wordt verlangd en op de vermogensmarkt ook kan worden verkregen. Deze opbrengstvoet zal hoger zijn naarmate daarin een hogere risicopremie wordt opgenomen. Vanuit het standpunt van de verschaffers van het eigen vermogen, wordt het risico verbonden met de aandelen van een onderneming bepaald door twee elementen. In de eerste plaats door het bedrijfsrisico van de onderneming. Het bedrijfsrisico brengt tot uitdrukking de kans op meer of minder ernstige schommelingen in de bedrijfsresultaten (bruto winst + interest). In de tweede plaats wordt het risico van de vermogensverschaffers bepaald door het financiële risico. Dit financiële risico brengt tot uitdrukking de kans dat door de hefboomwerking van het vreemde vermogen, de schommelingen in de bedrijfsresultaten zich versterkt voortplanten in de netto winst. Het bedrijfsrisico is in het kader van onze beschouwing verder niet van belang. Het financiële risico echter wel.

Door schrijver dezes is elders uiteengezet dat de omvang van het financiële risico dient te worden gemeten aan de verhouding tussen de beurswaarde van het vreemde vermogen en de beurswaarde van het eigen vermogen van de onderneming ${ }^{9}$ ). Stelt $\mathrm{D}$ voor de beurswaarde van het vreemde vermogen en $\mathrm{S}$ de beurswaarde van het eigen vermogen, dan zal het financiële risico groter zijn naarmate $\mathrm{D} / \mathrm{S}$ groter is.

De in onderdeel A van deze paragraaf besproken opbrengstvoet voor het eigen vermogen $\left(\mathrm{k}_{\mathrm{e}}\right)$ is, gezien de wijze waarop deze werd afgeleid, verbonden met het financiële risico van de onderneming als geheel. Anders gezegd: de opbrengstvoet $\mathrm{k}_{\mathrm{e}}$ is gekoppeld met de verhouding D/S die het "gemiddelde" - voor de onderneming als geheel geldende - financiële risico weergeeft.

Enkele alinea's hiervoor werd geconstateerd dat de onderneming financiert met een verhouding tussen vreemd en eigen vermogen van $\mathrm{F} / \mathrm{E}$ (boekwaarde). Bij een marginale investering - dat is een investering die nog juist de vermogenskosten oplevert - zullen „beurswaarde” en ,boekwaarde” van het daarin vastgelegde vreemde en eigen vermogen per definitie aan elkaar gelijk zijn. Dit betekent dat bij een marginale investering het daarvoor aangewende eigen vermogen een financieel risico zal hebben van $\mathrm{F} / \mathrm{E}$. Daar het bij de berekening van de kosten van het totale vermogen gaat om het vaststellen van de afkapgrens voor de marginale investering zullen de vermogenskosten dus ook moeten worden bepaald op basis van de opbrengstvoet voor het eigen vermogen met een financieel risico van $\mathrm{F} / \mathrm{E}$ en niet van

9) L. Traas t.a.p. blz. 176. 
D/S. Dit heeft tot consequentie dat niet kan worden uitgegaan van de eerder besproken opbrengstvoet $k_{e}$ - die immers is gekoppeld aan het ,gemiddelde" financiële risico $\mathrm{D} / \mathrm{S}$ - maar dat in plaats daarvan zal moeten worden genomen de opbrengstvoet die is verbonden met het "marginale" financiële risico $F / E$. Deze laatste opbrengstvoet zullen wij hierna aanduiden als $\mathrm{k}_{{ }_{\theta}}^{1}$.

Behalve de opbrengstvoet (= kostenvoet) van het eigen vermogen verbonden met gemiddeld en marginaal financieel risico kan bovendien nog worden onderscheiden de opbrengstvoet die geldt indien er in het geheel geen financieel risico is. Deze situatie zal zich voordoen indien de onderneming volledig met eigen vermogen is gefinancierd ( $D / S$ resp. F/E worden dan immers nul). De opbrenstvoet voor het eigen vermogen bij afwezigheid van financieel risico zal worden weergegeven door het symbool $\mathrm{k}$.

Elders is door schrijver dezes aangetoond dat er bij een rationeel gedrag van de vermogensverschaffers een vast verband bestaat tussen de besproken opbrengstvoeten $\mathrm{k}_{e}, \mathrm{k}_{e}^{1}$ en $\mathrm{k}$. Teneinde dit verband te kunnen weergeven worden de volgende symbolen geïntroduceerd:

$$
\begin{aligned}
\mathrm{H}=\mathrm{D} / \mathrm{S} \text { is vreemd : eigen vermogen gemeten aan de beurswaarde } \\
\mathrm{h}=\mathrm{F} / \mathrm{E} \text { is vreemd : eigen vermogen gemeten aan de balanswaarde } \\
\lambda=\text { de winstbelastingquote } \\
\mathrm{i}=\text { de interestvoet op vreemd vermogen welke geldt voor de beleggers } \\
\mathrm{k}_{\mathrm{i}}=\text { de interestvoet op vreemd vermogen welke geldt voor de onder- } \\
\text { neming. }
\end{aligned}
$$

Het verband tussen de opbrengstvoet bij gemiddeld financieel risico $\mathrm{k}_{\mathrm{e}}$ en de opbrengstvoet bij géén financieel risico $\mathrm{k}$ is neergelegd in formule (5): ${ }^{10}$ )

$$
K=\frac{k_{e}+(1-\lambda) k_{i} H}{1+(1-\lambda) \frac{k_{1}}{i} H}
$$

Het verband tussen $\mathrm{k}$ en de opbrengstvoet bij marginaal financieel risico $\mathrm{k}_{\mathrm{e}}$ blijkt uit de formule (6): ${ }^{10}$ )

$$
k_{e}^{1}=k+(1-\lambda)(k-i) \frac{k_{1}}{i} h
$$

Met behulp van deze beide formules kan de in onderdeel A besproken opbrengstvoet $k_{\mathrm{e}}$ in twee fasen worden herleid tot de voor de berekening van de kosten van het totale vermogen vereiste opbrengstvoet $k_{e}^{1}$. Zowel met betrekking tot de financiële structuur als ten aanzien van het financieel risico is hiermee de te volgen gedragslijn beschreven en dus kan nu ook de formule van de berekening van de kosten van het totale vermogen worden opgesteld. Het is doelmatig de kosten van het totale vermogen - aangeduid met $\mathrm{C}$ - te definiëren inclusief winstbelasting. De formule wordt dan

$$
\mathrm{C}=\frac{\mathrm{k}_{\theta}^{1}}{1-\lambda} \mathrm{F} / \mathrm{K}+\mathrm{k}_{\mathrm{i}}^{\mathrm{F}} / \mathrm{K}
$$

De formules (5) $t / m$ (7) vormen tezamen met de formule (4) uit onderdeel A de einduitkomst van onze analyse. Aan de hand van deze formules zullen wij in de volgende paragraaf trachten voor enkele ondernemingen de kosten van het eigen vermogen alsmede de kosten van het totale vermogen kwantitatief te bepalen.

10) Voor de aflciding van deze formule zij verwezen naar L. Traas t.a.p. blz. 139-171 alsmede blz. 242 en 243. 


\section{$\$ 3$ De eigenlijke meting van de vermogenskosten}

Zoals reeds in de Inleiding werd gezegd zijn een vijftal internationale concerns als onderwerp van onderzoek gekozen; nl. de Koninklijke Nederlandsche Petroleum Maatschappij, Philips' Gloeilampenfabrieken en Unilever N.V., alsmede General Electric en Radio Corporation of America. Voor elk van deze concerns zijn voor een periode van 12 jaar - van $1956 \mathrm{t} / \mathrm{m} 1967$ - per jaar achteraf de vermogenskosten berekend. Uit het in de vorige paragraaf gestelde volgt dat het eerste stadium in de berekening bestaat uit de bepaling van de opbrengstvoet $k_{e}$. Daarmee wordt dan ook begonnen.

\section{A. De opbrengstvoet voor het eigen vermogen bij gemiddeld financieel risico $\left(\mathrm{k}_{\mathrm{e}}\right)$}

De opbrengstvoet $k_{\mathrm{e}}$ dient te worden bepaald aan de hand van formule (4). Deze luidde:

(4) $\mathrm{k}_{\mathrm{e}}=\mathrm{Y}_{1} / \mathrm{P}_{\mathrm{o}}+\mathrm{x}(\mathrm{b}+\mathrm{u})$

Voor de grootheden in het rechter deel van (4) zullen de voor de betreffende concerns geldende $\mathrm{kwantitatieve} \mathrm{waarden} \mathrm{moeten} \mathrm{worden} \mathrm{vastgesteld.}$

$Y_{1} / P_{o}: P_{0}$ geeft weer de beurswaarde van een aandeel op tijdstip nul. Aangezien de beurskoers soms op korte termijn door toevallige faktoren niet onbelangrijk fluctueert werd voor $\mathrm{P}_{\mathrm{o}}$ niet de waarde op een bepaald tijdstip genomen, doch de gemiddelde waarde gedurende een jaar. Deze gemiddelde waarde werd berekend als het gemiddelde van de hoogste en laagste koers per maand gedurende 12 maanden. Voor de Nederlandse ondernemingen werden gebruikt de koersen van de Amsterdamse Effectenbeurs; voor de Amerikaanse ondernemingen de koersen van de New York Stock Exchange.

$\mathrm{Y}_{1}$ stelt voor de netto winst per gewoon aandeel die in het op het tijdstip nul volgende jaar door de aandeelhouders wordt verwacht. Bij onze berekeningen zijn wij echter uitgaan van de gedurende een bepaald jaar per aandeel werkelijk gemaakte netto winst. In feite werd dus met betrekking tot de winst van het lopende jaar „perfect foresight” bij de aandeelhouders verondersteld. Gezien de in vele gevallen vrij redelijke schattingen die beleggingsanalysten plegen te publiceren lijkt deze hypothese voor ons doel aanvaardbaar. De berekening van de nettowinst per aandeel werd gebaseerd op de aan gewone aandeelhouders toekomende netto winst. Eventuele preferente dividenden en/of aan andere winstgerechtigden toekomende bedragen werden in mindering gebracht.

Uitgaande van de voor $Y$ en $P$ per jaar gevonden waarden werd voor elk van de 5 ondernemingen gedurende de periode 1956-1967 de relatie Y/P bepaald.

Deze relatie kan zoals gezegd worden aangeduid als het omgekeerde van de „price-earnings ratio". De gevonden uitkomsten zijn vermeld in de tabellen $1 \mathrm{t} / \mathrm{m} 5$ welke als bijlagen bij dit artikel zijn gevoegd. Bovendien zijn zij in beeld gebracht in Grafiek I. ${ }^{11}$ )

11) Reeds thans zij erop gewezen dat teneinde voor de 5 ondernemingen een uniforme calculatiebasis te verkrijgen de cijfers van de N.V. Philips' Gloeilampenfabrieken werden gecorrigeerd voor het verschil tussen vervangingswaarde en historische kostprijs. Van de 5 onderzochte ondernemingen past alleen Philips de vervangingswaarde toe. De correctie op de Philipscijfers werd verricht aan de hand van het overzicht voor Amerikaanse aandeelhouders opgenomen in het jaarverslag van deze onderneming. De correctie had betrekking op twee grootheden $n . l$ op de netto winst per aandeel en op de omvang van het eigen vermogen.

$\mathrm{m} \mathrm{a} \mathrm{b}$ blz. 185 


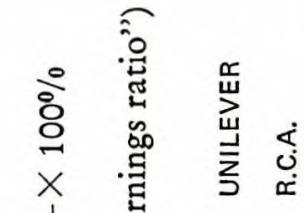
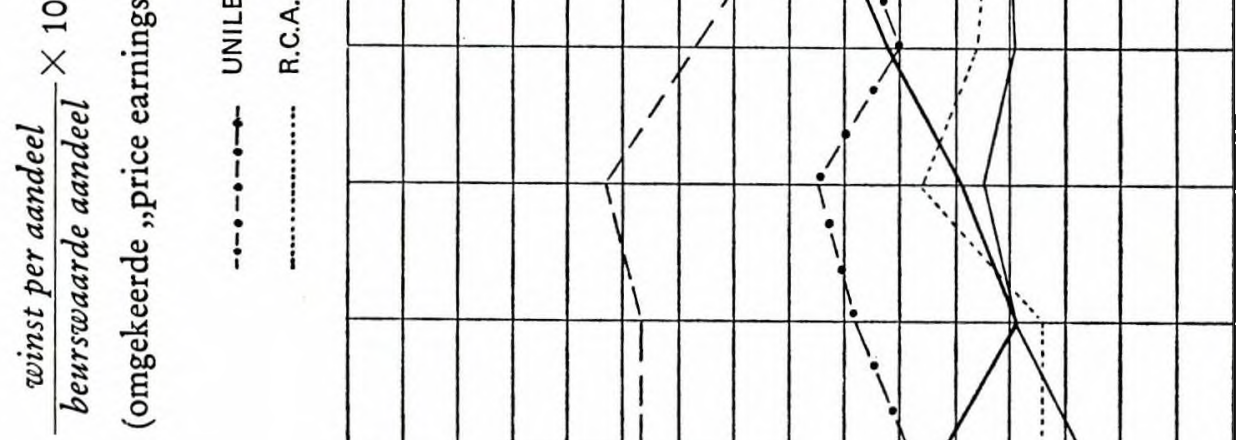

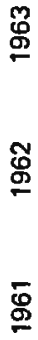

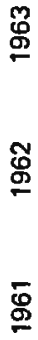

Ð

$\Phi$

$\nsubseteq$

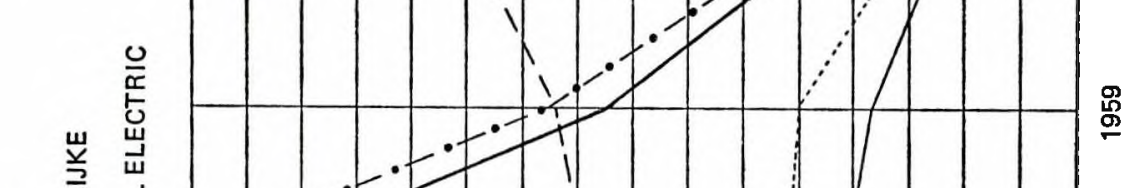

吕
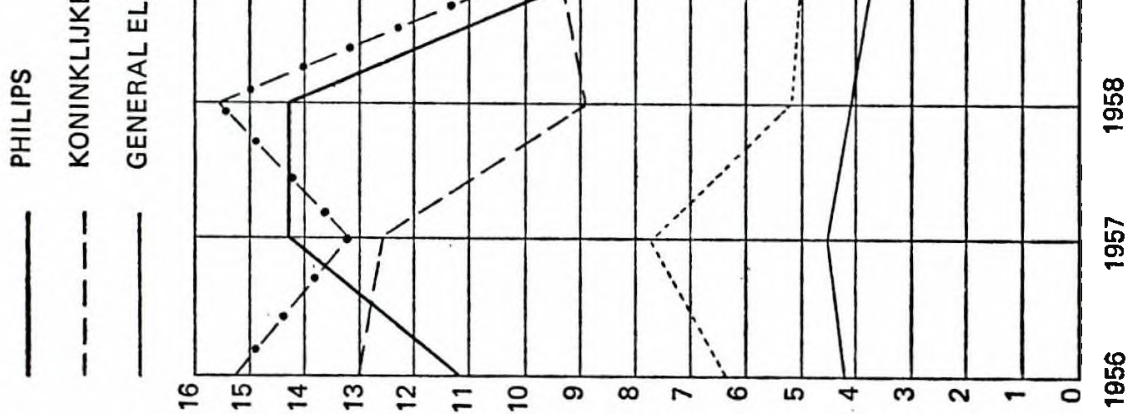
$(b+u)$ De inhoudingsquote (b) en de emissiequote (u) zijn verwachtingswaarden. $\mathrm{Zij}$ dienen weer te geven de verwachting die de aandeelhouders als groep met betrekking tot deze grootheden aanhouden. Door ons is verondersteld dat de aandeelhouders hun verwachtingen zullen vormen door een extrapolatie van de in het verleden voor deze grootheden geconstateerde "gemiddelde" waarden. Dit lijkt verleden voor deze grootheden geconstateerde "gemiddelde" waarden.

Voor elk van de 5 ondernemingen werd gedurende het tijdvak 1952-1967 per jaar de waarde van b berekend. Het daaruit resulterende beeld was zodanig dat voor 4 van de 5 ondernemingen één waarde van b voor het gehele tijdvak representatief kan worden geacht. Alleen bij de „Koninklijke” heeft zich gedurende het onderzochte tijdvak een duidelijke verschuiving in de inhoudingspolitiek voorgedaan, zodat voor deze onderneming meerdere waarden moesten worden aangehouden.

Een berekening van u op jaarbasis heeft vanzelfsprekend geen zin. Daarom werd voor deze grootheid het gemiddelde voor het gehele tijdvak als uitgangspunt genomen. De voor $(b+u)$ tezamen aangehouden waarden zijn vermeld in de tabellen $1 \mathrm{t} / \mathrm{m} 5$.

$x$ Het grootste probleem bij het kwantificeren van de in formule (4) opgenomen grootheden levert het vaststellen van de verwachtingswaarde voor $\mathbf{x}$; of beter gezegd (gezien de defintie van $x$ als $x=r_{0}^{1}-Y / P$ ) de achter $x$ schuilgaande verwachtingswaarde voor $r_{0}^{1}$.

In onderdeel A van de vorige paragraaf werd $r_{0}^{1}$ omschreven als de differentieel bepaalde rentabiliteit op het in de toekomst additioneel te investeren eigen vermogen. Kort gezegd: $\frac{\text { toeneming van de netto winst }}{\text { toeneming van het eigen vermogen }}$ gemiddeld per jaar in de komende jaren.

Uit deze laatste omschrijving blijkt duidelijk dat $\mathrm{r}_{0}^{1}$ het verschil weergeeft tussen het rentabiliteitsniveau in het heden en het rentabiliteitsniveau in de toekomst.

Het lijkt redelijk om ervan uit te gaan dat de verwachtingswaarde voor een dergelijke "differentiële” grootheid door de betrokkenen niet rechtstreeks wordt geschat, doch - al of niet bewust - tot stand komt door eerst het integrale rentabiliteitsniveau voor de toekomst vast te stellen en vervolgens na te gaan welke differentiële waarde daarin - bij vergelijking met het heden - ligt opgesloten. Aansluitend op deze gedachtengang hebben wij de aangehouden verwachtingswaarde voor $r_{0}^{1}$ in twee fasen trachten te bepalen.

a. Allereerst is vastgesteld welke integrale rentabiliteit de aandeelhouders voor de toekomst waarschijnlijk zullen verwachten voor de onderneming als geheel. Deze toekomstige integrale rentabiliteit zal worden aangeduid als $\mathrm{r}_{0}^{\mathrm{f}}$; de definitie ervan luidt: $\frac{\text { totale netto winst }}{\text { totaal geînvesteerd eigen vermogen }}$ gemiddeld per jaar in de komende jaren.

$b$. Vervolgens is berekend welke waarde voor $r_{e}^{1}$ impliciet wordt aangehouden gegeven de buidige integrale rentabiliteit $\left(\mathrm{r}_{\theta}\right)$ en de voor de toekomst verwachte integrale rentabiliteit $\left(\mathrm{r}_{0}^{\mathbf{f}}\right)$.

Bij de uitwerking van deze beide stadia is voortgebouwd op de in paragraaf 2 
onder A als tweede gegeven afleiding voor formule (1) ${ }^{\mathrm{b}}$. Dit betekent dat er van is uitgegaan dat de toekomstverwachtingen van de aandeelhouders zich slechts uitstrekken over een beperkt tijdvak van $\mathrm{n}$ jaar.

ad a. De toekomstige integrale rentabiliteit ( $r_{n}^{f}$ )

Over de wijze waarop toekomstverwachtingen van beleggers worden gevormd bestaan enkele empirische onderzoekingen. Deze onderzoekingen hebben betrekking op de verwachtingen ten aanzien van het toekomstige niveau van de interestvoet. In de theorie zijn met betrekking tot de vorming van verwachtingen over het toekomstige interestniveau twee hypothesen naar voren gebracht.

Volgens de eerste hypothese, gelanceerd door Malkiel'12), verwacht de vermogensmarkt in het algemeen dat de interestvoet in de toekomst zal tenderen naar een "normaal" niveau dat kan worden geschat op basis van de ervaringen uit het verleden. De tweede hypothese - afkomstig van Duesenberry ${ }^{13}$ ) - stelt dat als de interestvoet stijgt de beleggers voor de toekomst een verdere stijging zullen verwachten en omgekeerd. Empirische onderzoekingen van Paish voor Engeland en van Kane en Malkiel voor de U.S.A. tonen aan dat de hypothese van Duesenberry alleen voor de (zeer) korte termijn geldigheid bezit; voor de wat langere termijn geven de verzamelde gegevens een bevestiging van de hypothese van Malkiel ${ }^{14}$ ).

Aangezien verwachtingen ten behoeve van de prijsbepaling van aandelen typisch betrekking hebben op de lange termijn, zullen ook wij van de ,normaal-niveauhypothese" uitgaan. Vanzelfsprekend is de empirische bevestiging van deze hypothese in de sfeer van de interestvorming, nog geen doorslaggevend bewijs dat zij ook geldt op het terrein van de rentabiliteitsverwachtingen waarmee wij ons bezighouden. Er bestaat echter op een aantal punten gelijkenis tussen deze beide terreinen en bovendien spreekt ook intuitief de ,normaal-niveau-hypothese" wel aan.

Uitgaande van deze hypothese is ter bepaling van de toekomstige integrale rentabiliteit $\left(r_{\theta}^{p}\right)$ de volgende procedure toegepast.

Op basis van de cijfers uit het verleden is per onderneming een voor de lange termijn als ,normaal” te achten rentabiliteitsniveau vastgesteld. Dit normale rentabiliteitsniveau correspondeert met de gemiddelde rentabiliteit van de onderneming over de afgelopen 15 a 20 jaar gecorrigeerd voor uitschieters. De aangehouden percentages voor de ,normale" rentabiliteit op het eigen vermogen ná belasting zijn:

$10,0 \%$ voor Koninklijke Ned. Petroleum Maatschappij

$12,5 \%$ " Philips' Gloeilampenfabrieken ${ }^{15}$ )

$12,5 \% \quad, \quad$ Unilever N.V.

$18,0 \% \quad$, General Electric

$13,0 \%$ " Radio Corporation of America.

Naast het ,normale” is vervolgens het ,aktuele” rentabiliteitsniveau berekend. Teneinde ook hier min of meer incidentele fluctuaties te elimineren is gekozen voor

12) B. G. Malkiel „Expectations, bond prices and the term structure of interest rates”. Quarterly Journal of Economics, mei 1962.

13) J. Duesenberry „Business Cycles and Economic Growth”. McGraw Hill New York 1958.

${ }^{14)}$ E. J. Kane en B. G. Malkiel "The term structure of interest rates: an anlysis of a survey of interest rate expectations". The Review of economics and statistics, augustus 1967. F. W. Paish "Long term and short term interest rates in the United Kingdom", Manchester University Press. Manchester 1966.

15) Zie voetnoot 11. 
een gemiddelde over 3 jaar nl. het gemiddelde van de rentabiliteit in het eerstkomende jaar, in het betreffende jaar en in het afgelopen jaar. Bij de berekening van dit gemiddelde zijn aan deze drie jaren verschillende gewichten toegekend en wel resp. 3, 2 en 1 . De keuze van deze gewichten berust niet op een diepgaand onderzoek, doch op de eenvoudige overweging dat de toekomst in dit verband belangrijker is dan het heden en het heden belangrijker dan het verleden. De rentabiliteit voor het eerstkomende jaar - en tot op zekere hoogte ook die voor het betreffende jaar - is voor de vermogensmarkt een verwachtingswaarde. Wij zijn evenwel van de werkelijk gerealiseerde rentabiliteitscijfers uitgegaan en hebben dus ten opzichte van deze grootheden „perfect foresight" verondersteld; met de beperking echter dat een verandering van het rentabiliteitspercentage in het eerstkomende ten opzichte van het betreffende jaar voor zover deze verandering méér dan 2,5 punten bedroeg niet is meegenomen.

Gegeven het aldus gedefiniëerde ,aktuele" rentabiliteitsniveau voor elk jaar en gegeven het hiervoor genoemde „normale" rentabiliteitsniveau, is tenslotte de elk jaar voor de daarop volgende jaren verwachte integrale rentabiliteit $\left(\mathrm{r}_{\theta}^{p}\right)$ bepaald door het „aktuele" rentabiliteitscijfer te corrigeren voor de belft van het verschil tussen de "aktuele” en de „normale” rentabiliteit. De verkregen uitkomsten zijn opgenomen in de tabellen $1 \mathrm{t} / \mathrm{m} 5$.

ad b. De toekomstige differentiële rentabiliteit (r $\frac{1}{\theta}$ ) In de tweede fase moet uit de toekomstige integrale rentabiliteit $\left(\mathrm{r}_{\mathbf{a}}^{\mathfrak{f}}\right)$ de gezochte differentiële rentabiliteit $\left(\mathrm{r}_{\mathrm{\theta}}^{1}\right)$ worden berekend.

De definitie van $\mathrm{r}_{n}^{1}$ luidt:

$$
\frac{\text { toeneming netto winst gedurende } \mathrm{n} \text { jaar }}{\text { toeneming eigen vermogen gedurende } \mathrm{n} \text { jaar }}
$$

De toeneming van de netto winst is gelijk aan het verschil tussen de som van de jaarlijkse netto winsten die in de komende $n$ jaar naar verwachting zullen worden verkregen en de som van de jaarwinsten die gedurende $\mathrm{n}$ jaar zouden worden verkregen indien de netto winst elk jaar weer gelijk zou zijn aan de huidige netto winst.

De huidige netto winst is gelijk aan $r_{e} E_{o}\left(E_{o}\right.$ is het eigen vermogen). De laatstgenoemde som kan dus worden weergegeven door $\mathrm{n} \mathrm{re}_{\mathrm{e}} \mathrm{E}_{o}$ en de eerstgenoemde som kan worden gedefinieerd als:

$$
\mathrm{r}_{\mathrm{\theta}}^{r} \stackrel{\mathrm{n}}{=} \mathrm{E}_{\mathrm{o}}(1+\mathrm{g})^{\mathrm{t}}
$$

waarbij $g$ weergeeft de groeivoet van het eigen vermogen.

De toeneming van het eigen vermogen (de noemer in de definitie van $r_{\theta}^{1}$ ) kan gebruik makend van de zojuist genoemde symbolen worden omschreven als:

$$
\mathfrak{t} \stackrel{n}{=} E_{0}(1+g)^{t}-n E_{0}
$$

$\mathrm{Na}$ substitutie van de gevonden waarden en na uitwerking van de som en deling door $\mathrm{E}_{\circ}$ ontstaat:

$$
r_{0}^{!}=\frac{\left\{\frac{(1+g)^{n+1}-(1+g)}{g}\right\} r_{e}^{p}-r \cdot n}{\left\{\frac{(1+g)^{n+1}-(1+g)}{g}\right\}-n}
$$


Aangezien blijkens het eerder gestelde, het eigen vermogen jaarlijks zal toenemen met een gedeelte $(b+u)$ van de netto winst en de toekomstige rentabiliteit $\mathbf{r}_{\theta}^{p} \quad$ zal bedragen, kan de groeivoet $\mathrm{g}$ nader worden gedefinieerd als:

(9) $g=r_{\theta}^{f}(b+u)$

De formules (8) en (9) maken het mogelijk de waarde voor $r_{8}^{1}$ te bepalen gegeven de huidige rentabiliteit $r_{e}$, de verwachtingswaarden $b$, $u$ en $r_{\theta}^{f}$ alsmede het aantal jaren $(\mathrm{n})$ van de verwachtingshorizon. Met uitzondering van $\mathrm{n}$ is voor al deze grootheden in het voorgaande reeds aangegeven op welke wijze zij kunnen worden gekwantificeerd. Wordt ook voor de verwachtingshorizon een waarde gekozen dan kan dus $r_{e}^{1}$ worden berekend. Wij hebben de waarde voor u gesteld op 15 jaar. Een harde motivering kan daarvoor niet worden gegeven. Slechts kan worden gezegd dat men in de literatuur over groeiaandelen een tijdshorizon in deze orde van grootte wel vaker tegenkomt. Voor een verlenging van de horizon zijn de uitkomsten niet erg gevoelig; bij een belangrijke verkorting is de invloed duidelijker merkbaar.

De met behulp van de formules (8) en (9) berekende waarden van $r_{\theta}^{1}$ zijn ook nu weer vermeld in de tabellen $1 \mathrm{t} / \mathrm{m} 5$.

Uit de gevonden waarden van $r_{\theta}^{1}$ en de reeds eerder besproken waarden voor $\mathrm{Y} / \mathrm{P}$ kan tenslotte de voor toepassing van formule (4) vereiste grootheid $\mathrm{x}$ worden berekend. Ook voor de uitkomsten van deze berekening zij weer verwezen naar de tabellen $1 \mathrm{t} / \mathrm{m} 5$.

$\mathrm{Nu}$ ook x vaststaat zijn alle in de formule (4) voorkomende grootheden bekend zodat thans de grootheid waar het uiteindelijk om is begonnen - de beloningsvoet op het eigen vermogen $\left(k_{e}\right)$ - kan worden bepaald. De voor $k_{e}$ gevonden waarden zijn vermeld in de tabellen $1 \mathrm{t} / \mathrm{m} 5$, alsmede in de nevenstaande Grafiek II. Daaruit blijkt dat de gevonden waarden globaal genomen liggen tussen $10 \%$ en $12 \%$.

\section{B. De opbrengstvoet voor het eigen vermogen bij afwezigheid van financieel risico $(\mathrm{k})$}

De volgende stap in het eerder geschetste routeschema voor de berekening van de vermogenskosten is de herleiding van $k_{e}$ tot de opbrengstvoet $k$ die zou gelden indien de betreffende onderneming volledig met eigen vermogen zou zijn gefinancierd; dus vrij zou zijn van financieel risico.

Voor deze herleiding werd formule (5) geïntroduceerd welke luidde:

$$
k=\frac{k_{e}+(1-\lambda) k_{1} H}{1+(1-\lambda) \frac{k_{t}}{i} H}
$$

De in (5) voorkomende grootheden werden als volgt gekwantificeerd: $\lambda$ stelt voor de winstbelastingquote. Daarvoor werd genomen het percentage van de bruto winst dat door de jaren heen volgens de jaarverslagen van de betreffende ondernemingen gemiddeld aan winstbelasting diende te worden betaald.

$H$ geeft weer de relatie vreemd : eigen vermogen gemeten aan de beurswaarde (dus D/S). 


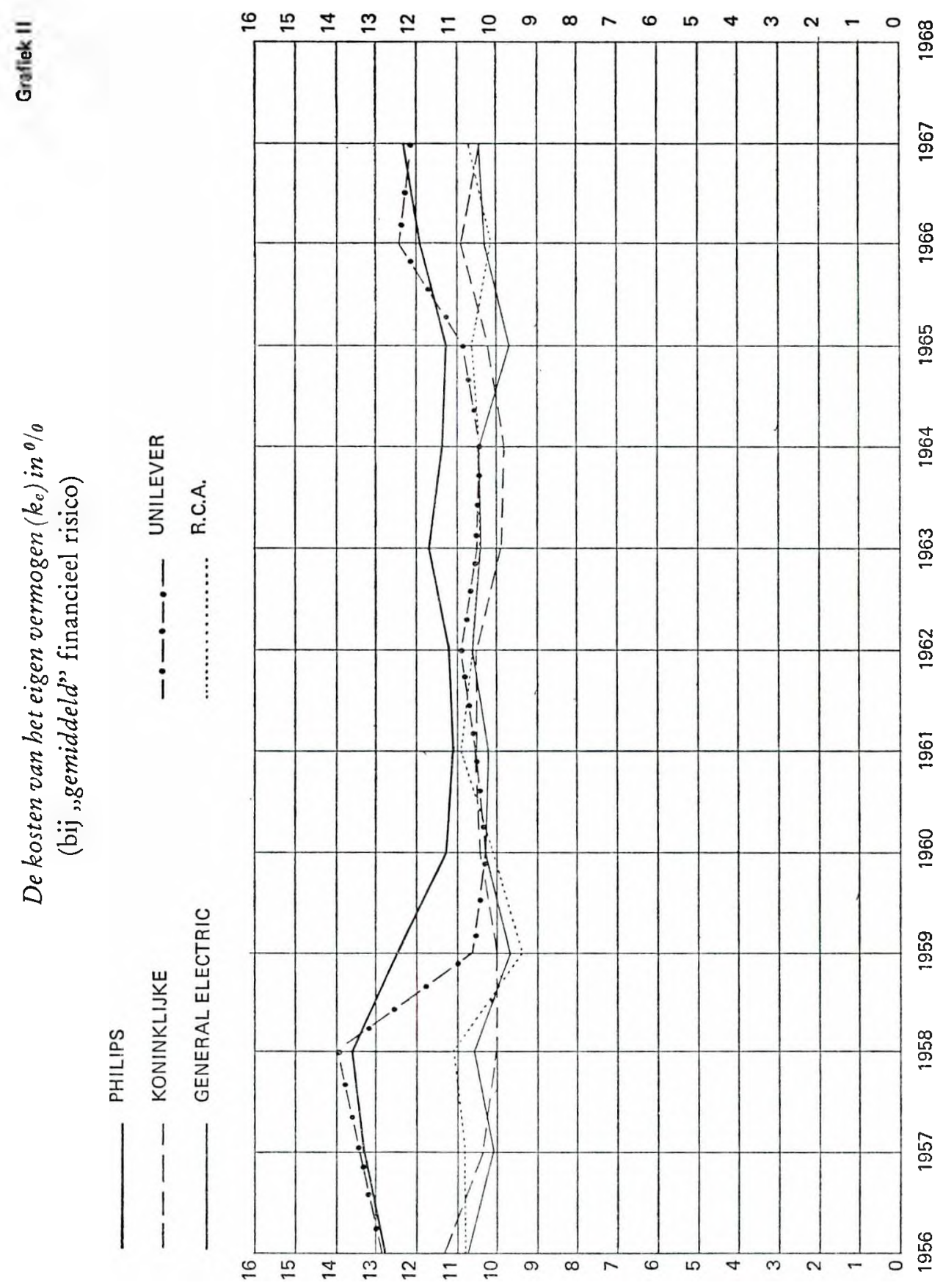


$D$ Eenvoudigheidshalve werden in het onderzoek onder vreemd vermogen begrepen alle vermogenssoorten behalve het aan de gewone aandeelhouders toekomende vermogen. Dit betekent dat ook posten als „minderheidsbelang”, , preferent aandelenkapitaal" en ,converteerbare obligaties”als vreemd vermogen werden meegenomen. In theorie is dit niet juist. Daar de uitkomsten echter bij een theoretisch perfecte opzet, naar het zich laat aanzien, niet noemenswaardig zouden veranderen, is voor deze eenvoudige oplossing gekozen. Om dezelfde reden is bij de kwantificering van het vreemde vermogen ook geabstraheerd van het verschil tussen boekwaarde en marktwaarde. Het vreemde vermogen (D) is dus per saldo eenvoudig gelijk gesteld aan het bedrag dat volgens de balansen van de betreffende ondernemingen niet toek wam aan gewone aandeelhouders.

$S$ De beurswaarde van het eigen vermogen werd berekend door het totaal van de uitstaande aandelen te vermenigvuldigen met de beurswaarde per aandeel $(P)$ vastgesteld zoals hiervoor besproken.

$i$ De voor de beleggers relevante interestvoet werd gesteld op $1 \%$ boven de rente op eeuwigdurende staatsleningen.

$k_{i}$ De door de onderneming gemiddeld te betalen interestvoet bleek een moeilijk te kwantificeren grootheid. Met name ook omdat daaronder mede dienden te worden begrepen de uitkeringen aan minderheidsaandeelhouders, houders van preferente aandelen, de kosten van leverancierskrediet in de vorm van gemiste korting voor contante betaling e.d. Voor elk van de ondernemingen werd op basis van de beschikbare gegevens een zo goed mogelijke schatting gemaakt van deze totale ,interestlast" per jaar. $\mathrm{Na}$ relatering daarvan aan het totale vreemde vermogen bleek dat voor elk van de ondernemingen een interestvoet resulteerde die globaal genomen gelijk was aan $75 \%$ van i. De voornaamste oorzaak van deze relatief lage interestvoet bleek te zijn gelegen in de vrij omvangrijke bedragen aan ,gratis" vreemd vermogen waarvan in de vorm van belastingschulden, nog te betalen kosten en (gedeeltelijk) leverancierskrediet gebruik kan worden gemaakt. Vooral ook omdat de in de jaarverslagen gepubliceerde gegevens voor de verschillende ondernemingen niet alle even gedetailleerd zijn werd $k_{1}$ voor de gehele groep gemakshalve gelijkgesteld aan de gevonden $0,75 \mathrm{i}$.

$\mathrm{Na}$ invulling in formule (5) van de kwantitatieve waarden voor de verschillende nu besproken grootheden kan de opbrengstvoet $\mathrm{k}$ worden berekend. De verkregen uitkomsten zijn in beeld gebracht in de bijgevoegde Grafiek III. Zoals uit deze grafiek blijkt liggen op enkele uitschieters na de gevonden percentages tussen de $9 \%$ en $10,5 \%$. Deze uitkomsten lijken een bevestiging te vormen voor het in de Amerikaanse literatuur vaak bij wijze van benadering genoemde percentage van 10.16)

Zoals te verwachten viel zijn de gevonden percentages voor $\mathrm{k}$ lager dan die voor $\mathrm{k}_{\mathrm{e}}$. Het financiële risico is nu immers geëlimineerd. In theorie geeft het verschil in niveau van de voor elk van de ondernemingen gevonden reeks van waarden voor $\mathrm{k}$, het verschil aan in bedrijfsrisico dat er tussen de 5 ondernemingen bestaat. Gezien de foutenmarge in de basisgegevens kunnen de uit Grafiek III blijkende verschillen echter slechts als een aanwijzing voor verschillen in bedrijfsrisico worden opgevat.

16) M. H. Miller in „Financial Research and Management Decisions”. A. A. Robichek ed.; John Wiley and Sons Inc. New York 1967 blz. 32 en 33.

m a b blz. 192 
三

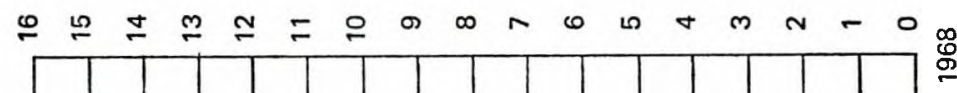

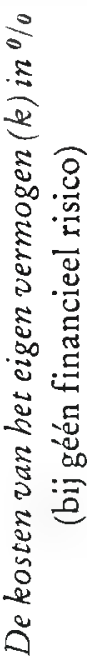

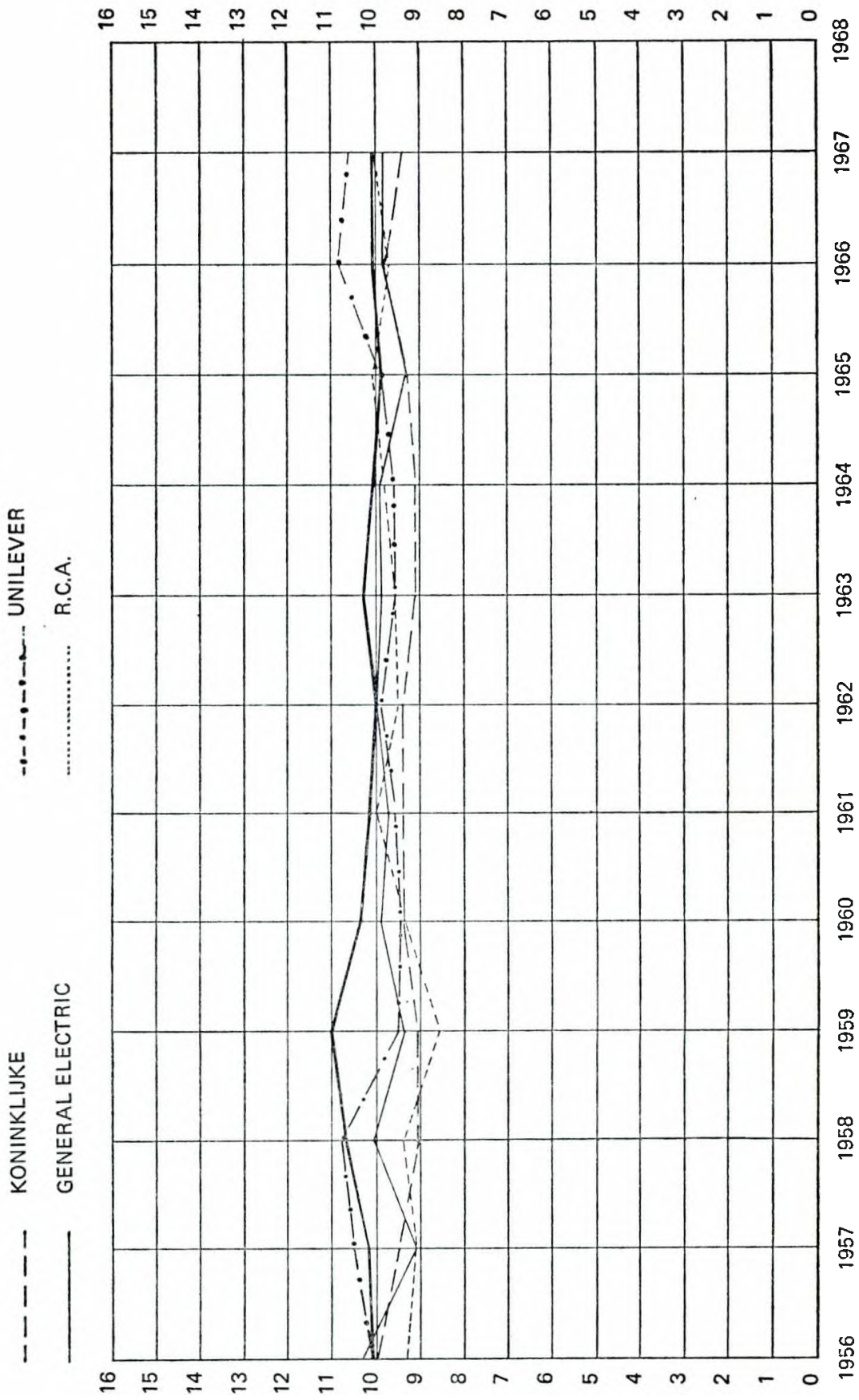

m a b blz. 193 
$\frac{\geq}{\frac{1}{0}}$

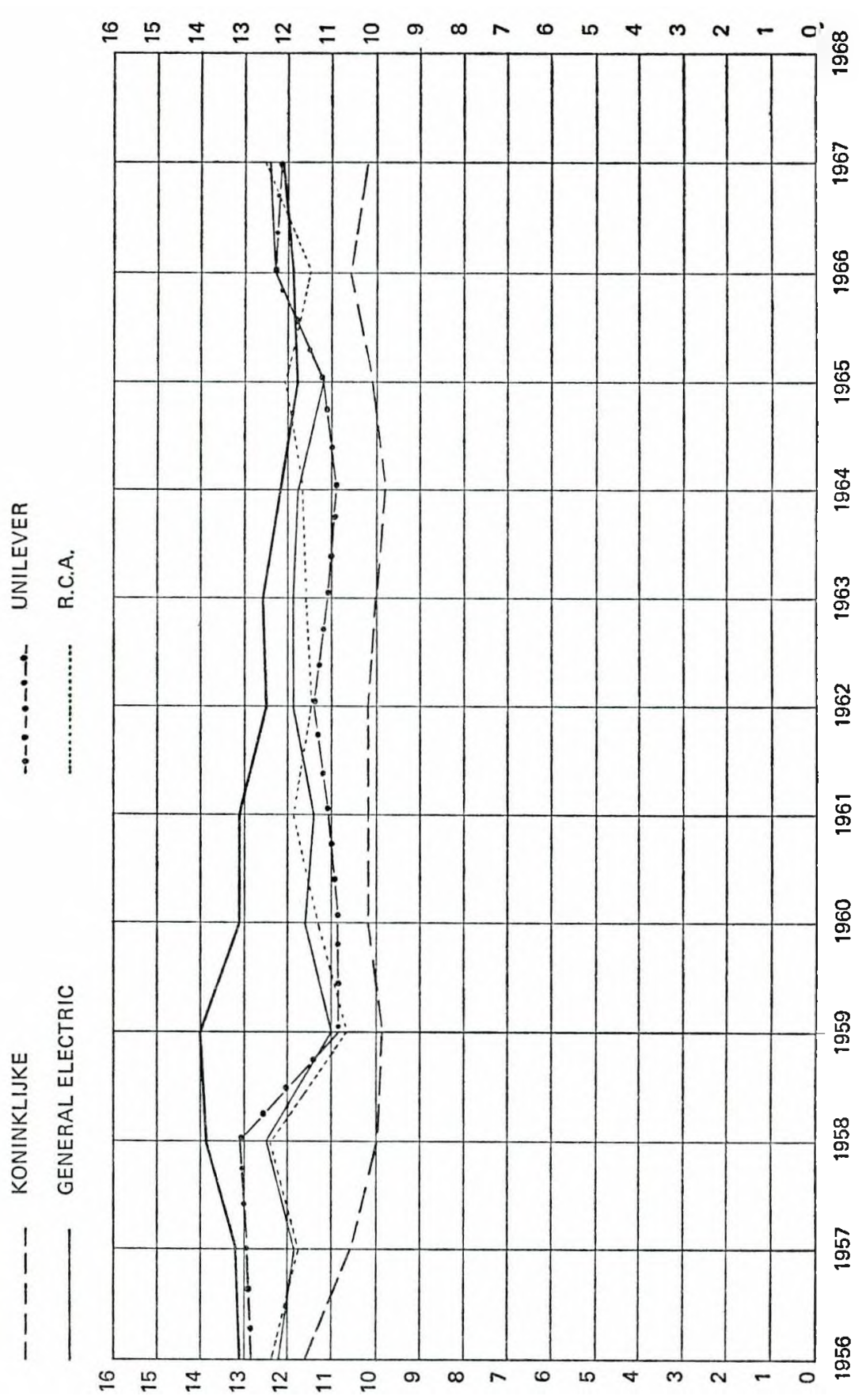

m a b blz. 194 


\section{De opbrengstvoet voor het eigen vermogen bij marginal financieel risico $\left(\mathrm{k},{ }_{4}^{1}\right)$}

De derde en laatste fase bij de berekening van de beloningsvoet op het eigen vermogen betreft de herleiding van de gevonden waarden voor $k$ tot de marginale beloningsvoet $k_{0}^{1}$. Deze herleiding dient te geschieden met behulp van de eerder genoemde formule (6). Deze formule luidde:

(6) $\mathrm{k}_{\mathrm{e}}^{1}=\mathrm{k}+(1-\lambda)(\mathrm{k}-\mathrm{i}) \frac{\mathrm{k}_{\mathrm{i}}}{\mathrm{i}} \mathrm{h}$

Met uitzondering van $h$ werden alle in formule (6) voorkomende grootheden hiervoor reeds besproken.

$b$ stelt voor de verhouding tussen vreemd en eigen vermogen gemeten aan de boekwaarden (dus $\mathrm{F} / \mathrm{E}$ ). Dit verhoudingsgetal werd voor de onderzochte ondernemingen eenvoudig bepaald op basis van de gegevens opgenomen in de geconsolideerde balans $\left.{ }^{17}\right)$. Aangezien bij de berekening van $\mathrm{H}(=\mathrm{D} / \mathrm{S})$ voor het vreemde vermogen eveneens de boekwaarde werd genomen (dus werd uitgegaan van de veronderstelling $\mathrm{D}=\mathrm{F}$ ) is het enige verschil tussen $\mathrm{H}$ en h gelegen bij het eigen vermogen: $\mathrm{H}$ is gebaseerd op het eigen vermogen tegen marktwaarde terwijl bij $\mathrm{h}$ de boekwaarde is genomen.

De uitkomsten die bij toepassing van formule (6) voor $\mathrm{k}_{\theta}^{1}$ werden verkregen zijn in beeld gebracht in Grafiek IV. Bij vergelijking van de verschillende ondernemingen blijkt dat de waarden voor $k_{\theta}^{1}$ veel verder uiteen liggen dan de waarden voor k opgenomen in Grafiek III. Dit behoeft geen verwondering te wekken aangezien het aandeel van het vreemde vermogen in de financiële structuur bij de verschillende ondernemingen niet gelijk is. Naarmate het vreemde vermogen relatief groter is zal het financiële risico belangrijker zijn en daardoor zal ook de waarde van $k_{0}^{1}$ hoger komen te liggen. Gezien het belang van de relatieve omvang van het vreemde vermogen voor de beoordeling van $k_{\theta}^{1}$ is dit gegeven in Grafiek V afzonderlijk in beeld gebracht.

\section{De kosten van bet totale vermogen}

$\mathrm{Nu}$ voor de verschillende ondernemingen de relevante kosten voor het eigen vermogen $\left(\mathrm{k}_{\theta}^{1}\right)$ zijn vastgesteld kunnen tenslotte ook de kosten van het totale vermogen voor elk van de ondernemingen worden berekend. Deze werden in $\$ 2$ gedefinieerd vóór aftrek van winstbelasting en wel volgens de formule:

$$
\mathrm{C}=\frac{\mathrm{k} \frac{1}{6}}{1-\lambda} \mathrm{E} / \mathrm{r}+\mathrm{k}_{1} \mathrm{~F} / \mathrm{k}
$$

Alle in deze formule voorkomende gegevens zijn in het voorgaande reeds ter sprake gekomen, zodat de wijze van $\mathrm{kwantificeren} \mathrm{thans} \mathrm{geen} \mathrm{verdere} \mathrm{toelichting}$ meer behoeft. Slechts zij er nog aan herinnerd dat de voor de onderneming geldende interestvoet voor het vreemde vermogen $\left(k_{i}\right)$ werd gesteld op 0,75i. De uitkomsten die bij toepassing van formule (5) werden verk regen zijn ook nu weer in beeld gebracht en wel in Grafiek VI.

17) Met dien verstande dat voor "General Electric” de niet geconsolideerde doch afzonderlijk vermelde „Finance Company" door ons in de geconsolideerde balans werd opgenomen. 


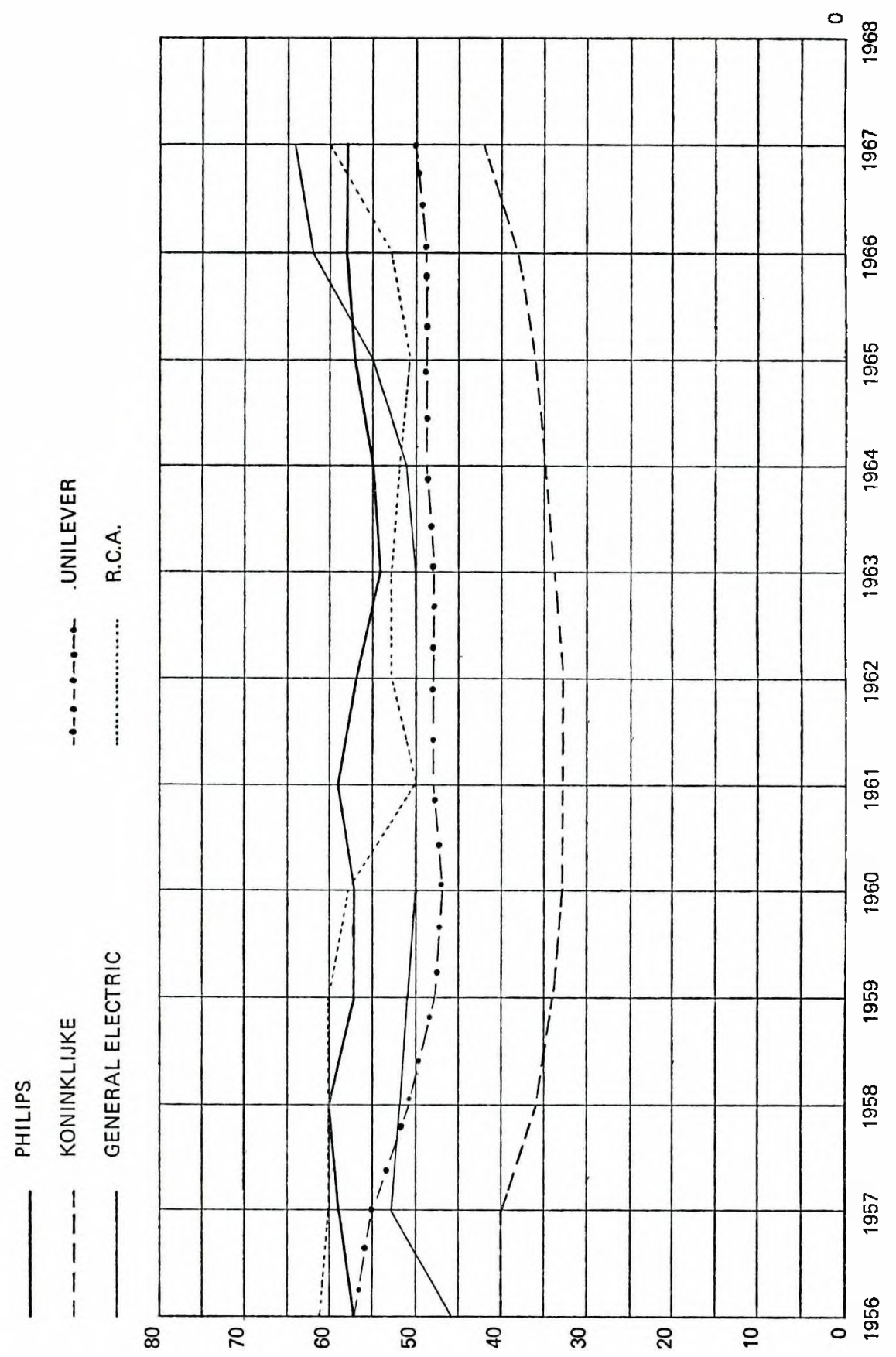


交

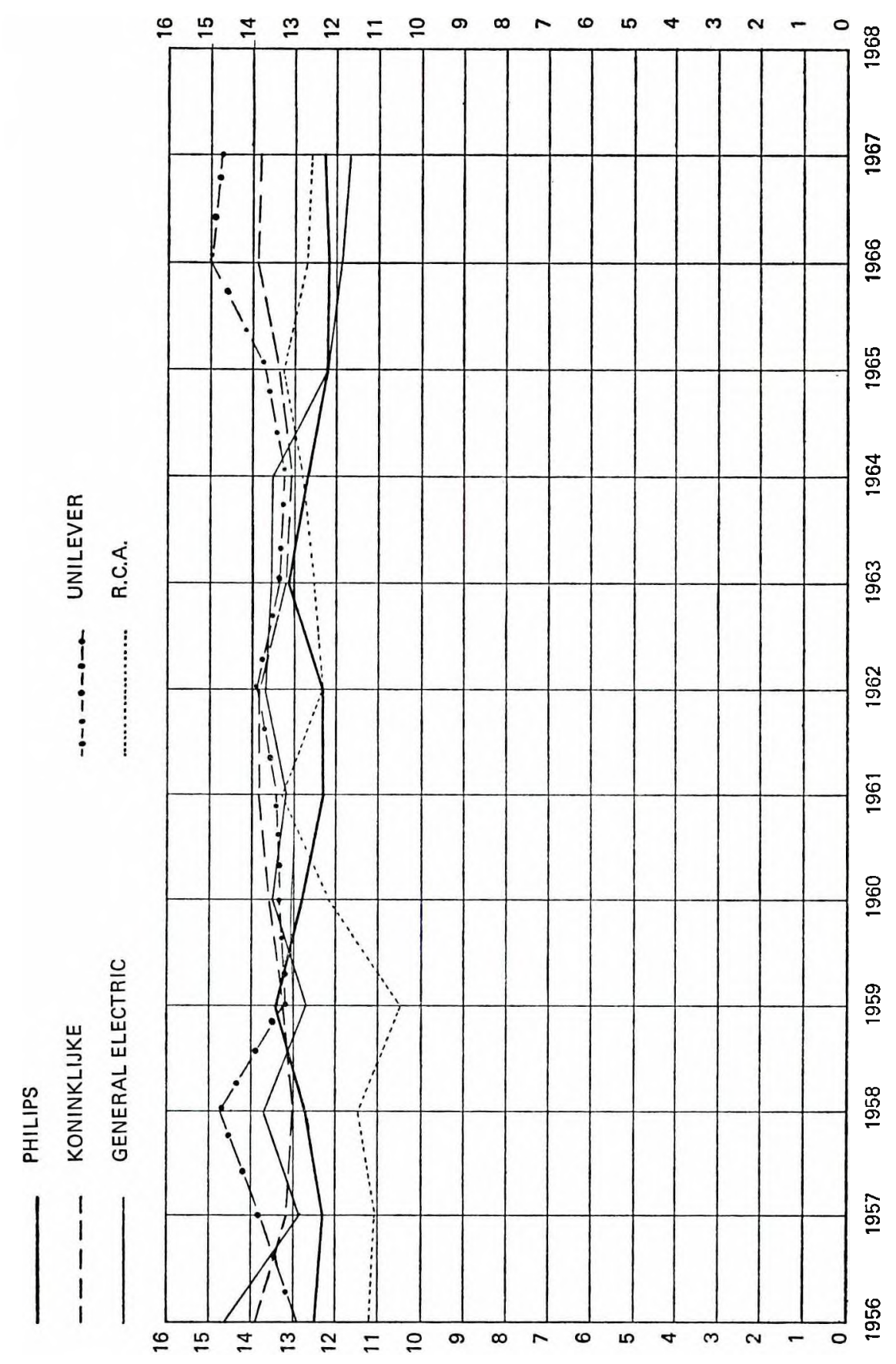

Oे 


\section{$\$ 4$ Beoordeling van de verkregen uitkomsten}

$\mathrm{Bij}$ de beoordeling van de verkregen uitkomsten dienen uiteraard de percentages die voor de kosten van het eigen vermogen werden berekend, centraal te staan. Uit de grafieken II, III en IV blijkt dat zich gedurende het onderzochte tijdvak slechrs betrekkelijk geringe veranderingen in de percentages hebben voorgedaan.

Opvallend is dat de fluctuaties het grootst zijn, en ook het niveau de neiging heeft wat hoger te liggen, aan het eind van de jaren vijftig. Wellicht duidt dit er op dat de wijziging in de waarderingsfilosofie die zich in de U.S.A. reeds in het midden van de jaren vijftig en in Europa wat later begon af te tekenen toen nog niet geheel was doorgezet. De bedoelde wijziging betrof de accentuering van het groei-element bij de waardering van aandelen. Het volgende citaat ontleend aan een voordracht van de Executive Vice President van de Morgan Guaranty Trust Company of New York brengt duidelijk tot uitdrukking wat dit inhield: „The concept of long-range earnings growth began to take hold in earnest, in the mid1950's. Analysts and investors paid less and less attention to „normal” earning power or even to earnings stability. They paid more and more attention to the fundamental competitive position of industries and companies, to changing processes and technologies, and to earnings projections over an extended time horizon". ${ }^{18)}$ De aan ons model ten grondslag liggende principes stemmen overeen met deze gewijzigde visie van de beleggingsanalysten.

De van jaar tot jaar in de gevonden percentages optredende veranderingen kunnen voor een deel worden toegeschreven aan het feit dat het toegepaste strak mechanische calculatiemodel niet zo gevoelig kon worden gemaakt dat alle in de realiteit optredende dynamiek daarin wordt gevangen. Bij kennis van de voor de verschillende ondernemingen geldende specifieke omstandigheden laten zich vele van de fluctuaties bijcorrigeren in de richting van het gemiddelde niveau. Als voorbeelden hiervan kunnen worden genoemd de relatief hoge percentages voor $k$ en $k_{\theta}$ bij Unilever in 1966 en 1967 en bij Philips in 1959. Voor Unilever heeft de beurs de winstvooruitzichten met betrekking tot 1966 en 1967 duidelijk veel te pessimistisch beoordeeld. Achteraf bleek dit pessimisme niet gerechtvaardigd en aangezien ons model ervan uitgaat dat de beurs één jaar vooruit betrekkelijk nauwkeurig schat, werden te hoge percentages berekend. Het hoge cijfer voor Philips in 1959 vindt zijn oorzaak in de omstandigheid dat deze onderneming in dat jaar het topniveau in de rentabiliteit bereikte (zie tabel 3 kolom 1). De beurs geloofde in het gehandhaafd blijven van een dergelijke hoge top kennelijk minder dan via ons model voor de verwachtingswaarden werd berekend. Deze enkele voorbeelden, die nog zouden kunnen worden uitgebreid, tonen aan dat het model niet zonder meer mechanisch dient te worden toegepast, maar dat de verkregen uitkomsten aan de hand van specifieke omstandigheden met verstand moeten worden beoordeeld. Dit laatste geldt ook vanwege een andere overweging van meer theoretische aard. Beziet men het verloop van de Philipscijfers voor $k_{e}$ in tabel 1 , dan blijkt dat de gevonden uitkomsten na 1959 betrekkelijk stabiel zijn. Plaatst men daarnaast het verloop van de verhouding vreemd : eigen vermogen gemeten aan de beurswaarde ( $\mathrm{H}$ in tabel 3) dan valt op de sterke veranderingen die zich in de loop van de tijd in deze verhouding hebben voorgedaan. Bij de theoretische beschouwingen in $\$ 2$

18) Wellicht ten overvloede zij erop gewezen dat ,normal earning power" hier werd bedoeld als "normale" winst per aandeel. Dat is dus iets heel anders dan een "normaal" rentabiliteitsniveau dat hiervoor bij de "normaal niveau hypothese" ter sprake kwam. 
werd gesteld dat naarmate $H$ kleiner wordt het financiële risico voor de belegger afneemt en derhalve de verlangde beloningsvoet $\mathrm{k}_{\mathrm{e}}$ lager zal komen te liggen; en omgekeerd. Dat de veranderingen in $\mathrm{H}$ slechts in geringe mate zijn gevolgd door veranderingen in $k_{e}$ lijkt erop te wijzen dat de beurs minder gevoelig is voor veranderingen in het financiële risico dan in de waarderingstheorie - en ook in ons model - wordt geconcludeerd. In het recente verleden hebben andere empirische onderzoekers deze indruk eveneens gekregen ${ }^{19}$ ). Dit zou betekenen dat de correctie voor het verschil tussen "gemiddeld" en "marginaal" financieel risico die op $\mathrm{k}_{\mathrm{e}}$ moest worden aangebracht om $\mathrm{k}_{\mathrm{u}}^{1}$ te vinden, wat te hoog zal zijn uitgevallen.

Uiteraard speelt deze correctie alleen een rol indien de intrinsieke waarde en de beurswaarde van de aandelen belangrijk uiteenlopen, immers alleen dan is er verschil tussen marginaal en gemiddeld financieel risico. Bij Philips treedt deze divergentie op in de jaren vóór 1965 (vergelijk de verschillen tussen $\mathrm{H}$ en h opgenomen in tabel 3 kolommen 9 en 10). De waarden die voor $\mathrm{k}_{0}^{1}$ werden geregistreerd moeten daarom voor Philips in die periode waarschijnlijk wat worden verlaagd, waardoor zij ook meer in lijn komen te liggen met de uitkomsten in 1965 en volgende jaren (zie Grafiek IV). Bij General Electric en R.C.A. lag de beurswaarde van de aandelen globaal genomen gedurende het gehele tijdvak boven de intrinsieke waarde zodat voor deze twee ondernemingen $\mathrm{k}_{\theta}^{1}$ voor alle jaren enigszins lager zal moeten worden gesteld. In welke mate precies de beurs minder op financieel risico reageert dan overeenkomt met de theorie is uiterst moeilijk vast te stellen en in elk geval op dit moment nog een open vraag. Daar echter de correctie die in verband daarmee eventueel op de door ons berekende waarden voor $k_{\theta}^{1}$ zal moeten worden aangebracht, slechts relatief gering zal zijn, wordt de bruikbaarheid van de verkregen uitkomsten daardoor niet wezenlijk aangetast ${ }^{20}$ ). Vanuit diverse andere gezichtspunten zou nog commentaar op de gevonden percentages kunnen worden gegeven. Wegens gebrek aan ruimte zullen wij ons echter tot het vorenstaande beperken.

Het geheel overziend achten wij de berekende percentages voor de kosten van het eigen vermogen zowel als voor de kosten van het totale vermogen voldoende betrouwbaar om daarmee in de praktijk te kunnen werken. De belangrijke operationele betekenis van de recente ontwikkelingen in de theorie van de financiering is met het vorenstaande dan ook naar onze mening aangetoond en, zoals in de "Inleiding" reeds werd gezegd, was dit het voornaamste doel van het onderhavige artikel. In het enige omvangrijke onderzoek dat tot nu toe in de U.S.A. werd uitgevoerd door Modigliani en Miller werden de vermogenskosten niet berekend voor een individuele onderneming, doch als een soort gemiddelde voor een bedrijfstak als geheel (nl. voor de „Electric Utility Industry") ${ }^{21}$ ). Een directe bepaling van de vermogenskosten per onderneming is met de methode van Modigliani en Miller ook niet mogelijk ${ }^{22}$ ). Naar wij thans menen te hebben aangetoond kan de theorie echter bepaald wèl voldoende bouwstenen leveren voor een calculatieschema geschikt

19) E. F. Brigham en M. J. Gordon „Leverage, dividend policy and the cost of capital". The Journal of Finance, maart 1968, speciaal blz. $97-102$.

20) De ,werkelijke" waarde voor $k_{\theta}^{1}$ zal immers moeten liggen tussen de door ons „berekende" waarde voor $k \frac{1}{v}$ en de waaide voor $k_{A}$.

21) M. H. Miller en F. Modigliani "Some estimates of the cost of capital to the Electric Utility Industry 1954 - 57". The American Economic Review, juni 1966. Alsmede het commentaar daarop in The American Economic Review, december 1967, blz. 1258 - 1300.

22) Modigliani en Miller; The American Economic Review, juni 1966, blz. 376.

m a b blz. 199 
voor de individuele onderneming. Vanzelfsprekend is met het vorenstaande beslist nog niet het laatste woord gezegd over het vraagstuk van de bepaling van de vermogenskosten voor de individuele onderneming; de geschetste methode kan slechts worden gezien als een eerste poging de theorie voor operationeel gebruik geschikt te maken. Op vele punten is nog een verdere verbreding en verdieping van inzicht nodig. Naar het schijnt is echter thans het stadium bereikt dat dit inzicht méér zal worden gediend door een systematische analyse van de empirische werkelijkheid dan door een verdere uitbouw van abstracte denkmodellen ${ }^{23}$ ).

23) Men denke bij het verdere onderzoek speciaal ook aan de problemen die zich voordoen bij de interpretatie van rentabiliteitspercentages zoals die door de ondernemingen worden gepubliceerd resp. uit de jaarverslagen kunnen worden berekend. Deze percentages behoeven niet noodzakelijk overeen te stemmen met wat Solomon noemde de ,true rate of return". Toch dient deze laatste het uitgangsgegeven te vormen in het calculatiemodel voor de bepaling van de vermogenskosten. Met het onderzoek van de problemen die hier liggen is nog nauwelijks een begin gemaakt. Slechts kan worden gewezen op het artikel van Solomon en Laya "Measurement of Company profitability: some systematic errors in the accounting rate of return"; opgenomen in: "Financial Research and Management Decisions". John Wiley and Sons inc. New York 1967. Voor de 5 door ons onderzochte concerns zijn, naar kan worden aangenomen, de afwijkingen tussen gepubliceerde rentabiliteit en ,true rate of return" van weinig of geen betekenis. Voor vele andere ondernemingen geldt dit echter niet.

Unilever N.V.

Tabel 1

\begin{tabular}{|c|c|c|c|c|c|c|c|c|c|c|}
\hline $\begin{array}{c}1 \\
\text { Jaar }\end{array}$ & $\begin{array}{l}2 \\
r_{e}\end{array}$ & $\begin{array}{l}3 \\
\mathbf{r}_{e}^{\mathrm{f}}\end{array}$ & $\begin{array}{l}4 \\
r_{\theta}^{2}\end{array}$ & $\begin{array}{c}5 \\
\mathrm{Y} / \mathrm{P}\end{array}$ & $\begin{array}{c}6 \\
x \\
(4-5)\end{array}$ & $\begin{array}{c}7 \\
x(b+u)\end{array}$ & $\begin{array}{c}8 \\
\mathrm{k}_{\mathrm{e}} \\
(5+7)\end{array}$ & $\begin{array}{c}9 \\
\mathrm{H}\end{array}$ & $\begin{array}{l}10 \\
h\end{array}$ & 11 \\
\hline 1967 & 11,6 & 11,9 & 12,3 & 11,9 & 0,4 & 0,2 & 12,1 & 1,01 & 0,99 & 6,7 \\
\hline '66 & 10,2 & 11,6 & 13,2 & 10,8 & 2,4 & 1,6 & 12,4 & 1,02 & 0,96 & 6,8 \\
\hline '65 & 10,8 & 11,6 & 12,5 & 7,6 & 4,9 & 3,2 & 10,8 & 0,68 & 0,96 & 6,2 \\
\hline '64 & 11,4 & 11,8 & 12,2 & 7,0 & 5,2 & 3,4 & 10,4 & 0,58 & 0,95 & 5,8 \\
\hline '63 & 10,7 & 11,7 & 12,8 & 6,1 & 6,8 & 4,4 & 10,5 & 0,50 & 0,93 & 5,4 \\
\hline '62 & 10,5 & 11,6 & 12,8 & 7,5 & 5,3 & 3,4 & 10,9 & 0,62 & 0,91 & 5,4 \\
\hline '61 & 11,1 & 11,8 & 12,5 & 6,8 & 5,7 & 3,7 & 10,5 & 0,56 & 0,93 & 5,2 \\
\hline '60 & 11,9 & 12,3 & 12,8 & 5,8 & 7,0 & 4,6 & 10,3 & 0,55 & 0,90 & 5,4 \\
\hline '59 & 15,2 & 13,1 & 11,1 & 9,6 & 1,6 & 1,0 & 10,6 & 0,71 & 0,94 & 5,3 \\
\hline '58 & 13,1 & 13,1 & 13,1 & 15,6 & $-2,5$ & $-1,6$ & 14,0 & 1,45 & 1,06 & 5,2 \\
\hline '57 & 12,2 & 12,8 & 13,5 & 13,2 & 0,3 & 0,2 & 13,4 & 1,43 & 1,20 & 5,2 \\
\hline '56 & 16,2 & 13,8 & 11,7 & 15,2 & $-3,4$ & $-2,2$ & 12,9 & 1,39 & 1,32 & 4,4 \\
\hline
\end{tabular}

Toelichting

$\begin{array}{ll}\mathrm{r}_{e} & =\text { rentab. eigen vermogen in het betreffende jaar in } \% \\ \mathrm{r}_{\mathrm{e}}^{\mathrm{f}} & =\text { verwachte gemiddelde rentab. voor de toekomst in } \% \\ \mathrm{r}_{\mathrm{e}}^{1} & - \text { verwachte marginale rentab. voor de toekomst in } \% \\ \mathrm{Y} / \mathrm{P} & =\text { omgekeerde "price earnings ratio" } \mathrm{x} 100 \\ \mathrm{x}(\mathrm{b}+\mathrm{u}) & - \text { groeicomponent zie formule }(4) \\ (\mathrm{b}+\mathrm{u}) & =0,65 \\ \mathrm{k}_{\mathrm{e}} & - \text { kosten eigen vermogen bij „gemiddeld" financieel risico } \\ \mathrm{H} & =\text { verhouding vreemd: eigen vermogen gemeten aan de beurswaarde } \\ \mathrm{h} & - \text { idem gemeten aan de boek waarde } \\ \mathrm{i} & - \text { interestpercentage lang vreemd vermogen }\end{array}$

$\mathrm{m}$ a b blz. 200 
N.V. Koninklijke Nederlandsche Petroleum Maatschappij

Tabel 2

\begin{tabular}{|c|c|c|c|c|c|c|c|c|c|c|}
\hline $\begin{array}{c}1 \\
\text { Jaar }\end{array}$ & $\begin{array}{l}2 \\
r_{e}\end{array}$ & $\begin{array}{l}3 \\
r_{e}^{p}\end{array}$ & $\begin{array}{l}4 \\
r_{e}^{1}\end{array}$ & $\begin{array}{c}5 \\
Y / P\end{array}$ & $\begin{array}{c}6 \\
x \\
(4-5)\end{array}$ & $x\left(b^{7}+u\right)$ & $\begin{array}{c}8 \\
k^{\circ} \\
(5+7)\end{array}$ & $\stackrel{9}{\mathrm{H}}$ & $\begin{array}{c}10 \\
\mathrm{~h}\end{array}$ & $\underset{\mathrm{i}}{11}$ \\
\hline 1967 & 9,0 & 9,5 & 10,2 & 10,7 & $-0,5$ & $-0,3$ & 10,4 & 0,93 & 0,72 & 6,7 \\
\hline '66 & 8,4 & 9,4 & 10,9 & 10,8 & $+0,1$ & $+0,1$ & 10,9 & 0,79 & 0,62 & 6,8 \\
\hline '65 & 8,4 & 9,2 & 10,5 & 9,6 & $+0,8$ & $+0,6$ & 10,2 & 0,63 & 0,55 & 6,2 \\
\hline '64 & 8,2 & 9,2 & 10,7 & 8,1 & $+2,6$ & $+1,7$ & 9,8 & 0,52 & 0,53 & 5,8 \\
\hline '63 & 8,8 & 9,3 & 10,1 & 9,6 & $+0,5$ & $+0,3$ & 9,9 & 0,51 & 0,52 & 5,4 \\
\hline '62 & 8,9 & 9,4 & 10,1 & 11,3 & $-1,2$ & $-0,8$ & 10,5 & 0,64 & 0,50 & 5,4 \\
\hline '61 & 8,5 & 9,3 & 10,4 & 10,7 & $-0,3$ & $-0,2$ & 10,5 & 0,65 & 0,49 & 5,2 \\
\hline 60 & 8,6 & 9,3 & 10,3 & 10,7 & $-0,4$ & $-0,3$ & 10,4 & 0,65 & 0,50 & 5,4 \\
\hline '59 & 9,2 & 9,6 & 10,2 & 9,4 & $+0,8$ & $+0,6$ & 10,0 & 0,54 & 0,51 & 5,3 \\
\hline '58 & 9,4 & 9,9 & 10,4 & 8,9 & $+1,5$ & $+1,1$ & 10,0 & 0,55 & 0,57 & 5,2 \\
\hline '57 & 16,0 & 12,5 & 9,6 & 12,6 & $-2,9$ & $-2,2$ & 10,4 & 0,50 & 0,66 & 5,2 \\
\hline '56 & 15,2 & 12,7 & 10,7 & 13,0 & $-2,3$ & $-1,7$ & 11,3 & 0,55 & 0,67 & 4,4 \\
\hline
\end{tabular}

Toelichting: zie tabel 1

$(b+u)=\operatorname{van} 1956 \mathrm{t} / \mathrm{m}^{\prime} 60: 0,75$

van $1961 \mathrm{t} / \mathrm{m}^{\prime} 62: 0,70$

van $1963 \mathrm{t} / \mathrm{m}^{\prime} 67: 0,65$

N.V. Philips' Gloeilampenfabrieken

Tabel 3

\begin{tabular}{|c|c|c|c|c|c|c|c|c|c|c|}
\hline $\begin{array}{c}1 \\
\text { Jaar }\end{array}$ & $\begin{array}{l}2 \\
r_{e}\end{array}$ & $\begin{array}{l}3 \\
r_{e}^{t}\end{array}$ & $\begin{array}{c}4 \\
r_{e}^{2}\end{array}$ & $\stackrel{5}{Y / P}$ & $\begin{array}{c}6 \\
x \\
(4-5)\end{array}$ & $\begin{array}{c}7 \\
x(b+u)\end{array}$ & $\begin{array}{c}8 \\
h_{e} \\
(5 \div 7)\end{array}$ & $\begin{array}{c}9 \\
\mathrm{H}\end{array}$ & $\begin{array}{l}10 \\
h\end{array}$ & 11 \\
\hline 1967 & 8,4 & 10,8 & 12,8 & 9,3 & 3,6 & 3,0 & 12,3 & 1,54 & 1,40 & 6,7 \\
\hline '66 & 9,3 & 11,0 & 12,3 & 9,5 & 2,8 & 2,4 & 11,9 & 1,41 & 1,39 & 6,8 \\
\hline '65 & 11,5 & 11,7 & 11,8 & 8,5 & 3,3 & 2,8 & 11,3 & 0,97 & 1,30 & 6,2 \\
\hline '64 & 11,7 & 11,9 & 12,1 & 7,3 & 4,9 & 4,1 & 11,4 & 0,75 & 1,20 & 5,8 \\
\hline 63 & 10,3 & 11,7 & 12,7 & 6,2 & 6,5 & 5,5 & 11,7 & 0,71 & 1,16 & 5,4 \\
\hline '62 & 11,0 & 11,7 & 12,3 & 4,9 & 7,4 & 6,3 & 11,2 & 0,62 & 1,31 & 5,4 \\
\hline '61 & 12,3 & 12,4 & 12,5 & 3,9 & 8,5 & 7,2 & 11,1 & 0,47 & 1,44 & 5,2 \\
\hline 60 & 16,9 & 14,0 & 12,3 & 5,3 & 7,0 & 6,0 & 11,3 & 0,42 & 1,32 & 5,4 \\
\hline 59 & 17,7 & 14,8 & 13,3 & 8,5 & 4,8 & 4,0 & 12,5 & 0,70 & 1,34 & 5,3 \\
\hline 58 & 15,4 & 14,2 & 13,5 & 14,3 & $-0,8$ & $-0,7$ & 13,6 & 1,36 & 1,47 & 5,2 \\
\hline 57 & 13,7 & 13,3 & 13,2 & 14,3 & $-1,2$ & $-1,0$ & 13,3 & 1,52 & 1,45 & 5,2 \\
\hline '56 & 13,2 & 13,0 & 12,9 & 11,2 & 1,7 & 1,4 & 12,8 & 1,10 & 1,30 & 4,4 \\
\hline
\end{tabular}

Toelichting: zie tabel 1; zie ook voetnoot 11

$(b+u)=0,85$

m a b blz. 201 
General Electric

Tabel 4

\begin{tabular}{rcccccccccc}
\hline $\begin{array}{c}1 \\
\text { Jaar }\end{array}$ & $\begin{array}{c}2 \\
\mathrm{r}_{\mathrm{e}}\end{array}$ & $\begin{array}{c}3 \\
\mathrm{r}_{\mathrm{e}}^{\mathrm{e}}\end{array}$ & $\begin{array}{c}4 \\
\mathrm{r}_{\mathrm{e}}^{1}\end{array}$ & $\begin{array}{c}5 \\
\mathrm{Y} / \mathrm{P}\end{array}$ & $\begin{array}{c}6 \\
\mathrm{x} \\
(4-5)\end{array}$ & $\begin{array}{c}7 \\
\mathrm{x}+\mathrm{u})\end{array}$ & $\begin{array}{c}8 \\
\mathrm{k}_{\mathrm{e}} \\
(5+7)\end{array}$ & $\begin{array}{c}9 \\
\mathrm{H}\end{array}$ & $\begin{array}{c}10 \\
\mathrm{~h}\end{array}$ & $\begin{array}{c}11 \\
\mathrm{i}\end{array}$ \\
\hline 1967 & 15,9 & 17,0 & 18,1 & 4,2 & 14,0 & 6,3 & 10,4 & 0,46 & 1,8 & 5,9 \\
'66 & 15,7 & 17,0 & 18,5 & 3,6 & 14,9 & 6,7 & 10,3 & 0,38 & 1,6 & 5,8 \\
'65 & 17,5 & 17,3 & 17,0 & 3,7 & 13,3 & 6,0 & 9,7 & 0,26 & 1,2 & 5,2 \\
'64 & 16,6 & 17,4 & 18,2 & 4,0 & 14,3 & 6,4 & 10,4 & 0,25 & 1,0 & 5,2 \\
'63 & 15,9 & 17,1 & 18,4 & 3,9 & 14,4 & 6,5 & 10,4 & 0,25 & 1,0 & 5,0 \\
'62 & 16,0 & 16,9 & 18,0 & 4,5 & 13,5 & 6,1 & 10,6 & 0,28 & 1,0 & 5,0 \\
'61 & 15,5 & 16,7 & 18,0 & 3,8 & 14,1 & 6,4 & 10,2 & 0,25 & 1,0 & 4,9 \\
'60 & 13,5 & 16,3 & 19,6 & 2,7 & 16,9 & 7,6 & 10,3 & 0,20 & 1,0 & 5,0 \\
'59 & 20,2 & 18,5 & 17,0 & 3,7 & 13,3 & 6,0 & 9,7 & 0,19 & 1,0 & 5,1 \\
'58 & 19,1 & 18,9 & 18,7 & 4,1 & 14,6 & 6,6 & 10,6 & 0,23 & 1,1 & 4,4 \\
'57 & 20,9 & 19,0 & 17,2 & 4,5 & 12,6 & 5,6 & 10,1 & 0,25 & 1,1 & 4,5 \\
'56 & 19,1 & 18,9 & 18,7 & 4,2 & 14,6 & 6,6 & 10,7 & 0,18 & 0,9 & 4,1 \\
\hline
\end{tabular}

Toelichting: zie tabel 1

$(b+u)=0,45$

Radio Corporation of America

Tabel 5

\begin{tabular}{|c|c|c|c|c|c|c|c|c|c|c|}
\hline $\begin{array}{c}1 \\
\text { Jaar }\end{array}$ & $\begin{array}{l}2 \\
\mathrm{r}_{\mathrm{e}}\end{array}$ & $\begin{array}{l}3 \\
r_{\theta}^{\ell}\end{array}$ & $\begin{array}{l}4 \\
r_{e}^{1}\end{array}$ & $\begin{array}{c}5 \\
\mathrm{Y} / \mathrm{P}\end{array}$ & $\begin{array}{c}6 \\
x \\
(4-5)\end{array}$ & $\begin{array}{c}7 \\
x(b+u)\end{array}$ & $\begin{array}{c}8 \\
k_{e} \\
(5+7)\end{array}$ & $\stackrel{9}{\mathrm{H}}$ & $\begin{array}{l}10 \\
\mathrm{~h}\end{array}$ & ${ }_{\mathrm{i}}^{11}$ \\
\hline 1967 & 17,9 & 15,7 & 14,1 & 4,4 & 9,7 & 6,3 & 10,7 & 0,37 & 1,48 & 5,9 \\
\hline '66 & 20,4 & 16,1 & 13,1 & 4,6 & 8,5 & 5,5 & 10,1 & 0,25 & 1,13 & 5,8 \\
\hline '65 & 18,1 & 15,7 & 14,0 & 4,2 & 9,8 & 6,4 & 10,6 & 0,27 & 1,04 & 5,2 \\
\hline '64 & 15,4 & 14,4 & 13,6 & 4,4 & 9,2 & 6,0 & 10,4 & 0,33 & 1,08 & 5,2 \\
\hline '63 & 12,7 & 13,1 & 13,5 & 4,6 & 8,9 & 5,8 & 10,4 & 0,43 & 1,11 & 5,0 \\
\hline '62 & 10,6 & 11,9 & 13,3 & 5,6 & 7,7 & 5,0 & 10,6 & 0,62 & 1,13 & 5,0 \\
\hline '61 & 7,6 & 10,9 & 15,0 & 3,4 & 11,5 & 7,5 & 10,9 & 0,47 & 0,99 & 4,9 \\
\hline 160 & 8,7 & 11,0 & 13,7 & 3,4 & 10,3 & 6,7 & 10,1 & 0,44 & 1,14 & 5,0 \\
\hline '59 & 12,1 & 12,0 & 11,8 & 5,0 & 6,8 & 4,4 & 9,4 & 0,59 & 1,49 & 5,1 \\
\hline '58 & 10,0 & 12,0 & 14,3 & 5,2 & 9,1 & 6,0 & 11,1 & 0,83 & 1,49 & 4,4 \\
\hline '57 & 13,2 & 12,8 & 12,4 & 7,7 & 4,7 & 3,1 & 10,8 & 0,95 & 1,51 & 4,5 \\
\hline '56 & 14,6 & 13,8 & 13,2 & 6,4 & 6,8 & 4,4 & 10,8 & 0,74 & 1,57 & 4,1 \\
\hline
\end{tabular}

Toelichring: zie tabel 1

$(b+u)=0,65$

m a b blz. 202 